\title{
The Physiological Basis of the Genetic Progress in Yield Potential of CIMMYT Spring Wheat Cultivars from 1966 to 2009
}

\author{
K. A. B. Aisawi, M. P. Reynolds, R. P. Singh, and M. J. Foulkes`
}

\begin{abstract}
Our objective was to investigate the physiological basis of genetic progress in grain yield in CIMMYT spring wheat (Triticum aestivum L.) cultivars developed from 1966 to 2009 in irrigated, high-potential conditions. Field experiments were conducted during three growing seasons in northwest Mexico (2008-2009, 2009-2010, and 2010-2011) examining 12 historic CIMMYT semidwarf spring wheat cultivars released from 1966 to 2009. The linear rate of genetic gain in grain yield was $30 \mathrm{~kg} \mathrm{ha}^{-1}$ $\mathrm{yr}^{-1}\left(0.59 \% \mathrm{yr}^{-1} ; R^{2}=0.58, P=0.01\right)$. Grain yield progress was associated with increased aboveground dry matter (AGDM) at harvest $\left(R^{2}=0.80, P<\right.$ $0.001)$ and heavier grain weight $\left(R^{2}=0.46, P<0.05\right)$. There was a positive linear association between AGDM and plant height $\left(R^{2}=0.43, P<0.05\right)$ and between grain weight and the date of complete canopy senescence (CCS) among the 12 cultivars $\left(R^{2}=0.36, P<0.05\right)$. There was no change in grains per square meter or harvest index $(\mathrm{HI})$ with year of release (YoR). Grain weight was positively associated with potential grain weight (PGW), and PGW, in turn, was positively associated with rachis length per spikelet among the cultivars. Overall spike dry matter (DM) per square meter at anthesis (GS61) +7 $\mathrm{d}$ did not change with YoR. There was a trend for a linear increase in AGDM of fertile shoots (expressed as $\mathrm{g} \mathrm{m}^{-2}$ ) at GS61 $+7 \mathrm{~d}$ with YoR, but this was counteracted by spike partitioning decreasing overall during the $43-\mathrm{yr}$ period from 0.25 to 0.23 . There was a linear increase in preanthesis flag-leaf stomatal conductance with YoR $(P<0.05)$. There was no change in grain growth response to a degraining treatment imposed at GS61 $+14 \mathrm{~d}$ (mean grain weight response $+5.5 \%$ ) indicating that the degree of source limitation to grain growth appeared to be small and unchanged in the older and modern cultivars. Generally, these results indicated that the rate of genetic progress in CIMMYT spring wheat has slowed but has not plateaued in recent decades, while genetic gains were associated with increase in both potential and final grain weight.
\end{abstract}

K.A.B. Aisawi and M.J. Foulkes, Division of Plant and Crop Sciences, Univ. of Nottingham, Sutton Bonington Campus, Loughborough, Leicestershire, LE12 5RD, UK; M.P. Reynolds and R.P. Singh, CIMMYT International Maize and Wheat Improvement Center (CIMMYT), Km. 45, Carretera Mexico, El Batan, Texcoco, Mexico. Received 2 Sept. 2014. Accepted 17 Dec. 2014. *Corresponding author (John.Foulkes@nottingham.ac.uk).

Abbreviations: AGDM, aboveground dry matter; CCS, complete canopy senescence; CGR, crop growth rate; CTD, canopy temperature depression; DM, dry matter; FE, fruiting efficiency; GN, grain number per square meter; GPS, grains per spike; GS, growth stage; HI, harvest index; PGW, potential grain weight; RUE, radiation-use efficiency; SPI, spike-partitioning index; TGW, 1000-grain weight; WSC, watersoluble carbohydrate; YoR, year of release.

S EVERAL STUDIES have examined grain yield progress in sets of historic CIMMYT spring wheat cultivars and advanced lines. Waddington et al. (1986) observed genetic progress for 17 cultivars of $59 \mathrm{~kg} \mathrm{ha}^{-1} \mathrm{yr}^{-1}\left(1.1 \% \mathrm{yr}^{-1}\right)$ from 1950 to 1982 in northwest Mexico. Sayre et al. (1997) reported progress of grain yield in northwest Mexico for eight CIMMYT cultivars from 1962 to 1988 of $67 \mathrm{~kg} \mathrm{ha}^{-1} \mathrm{yr}^{-1}\left(0.88 \% \mathrm{yr}^{-1}\right)$. Manes et al. (2012) examined genetic progress globally in the CIMMYT semiarid wheat yield trials over a 17-yr period (1994 to 2010) and found grain yield as a percentage of the check cultivar Dharwar Dry increased at a rate of $31 \mathrm{~kg} \mathrm{ha}^{-1} \mathrm{yr}^{-1}\left(\sim 1 \% \mathrm{yr}^{-1}\right)$. The genetic grain yield progress of 26 spring wheat advanced lines released by CIMMYT from 1977 to 2008 was evaluated by Lopes et al. (2012); grain yield progress was linear and $\sim 35 \mathrm{~kg} \mathrm{ha}^{-1} \mathrm{yr}^{-1}\left(0.7 \% \mathrm{yr}^{-1}\right)$. Generally, these

Published in Crop Sci. 55:1749-1764 (2015).

doi: 10.2135/cropsci2014.09.0601

Freely available online through the author-supported open-access option.

(C) Crop Science Society of America | 5585 Guilford Rd., Madison, WI 53711 USA

All rights reserved. No part of this periodical may be reproduced or transmitted in any form or by any means, electronic or mechanical, including photocopying, recording, or any information storage and retrieval system, without permission in writing from the publisher. Permission for printing and for reprinting the material contained herein has been obtained by the publisher. 
investigations indicated that the rate of genetic progress in CIMMYT spring wheat has slowed but has not plateaued in recent decades. There are also several other studies worldwide that do show recent genetic gains for wheat yield potential, for example, Zhou et al. (2007), Zheng et al. (2011) and Xiao et al. (2012) in China; Peltonen-Sainio et al. (2009) in Finland; Shearman et al. (2005), Mackay et al. (2011), and Clarke et al. (2012) in the United Kingdom; Sanchez-Garcia et al. (2013) in Spain; and Sadras and Lawson (2011) in Australia. However, there are also some cases in which the genetic progress appears to be showing a plateau, for example, winter wheat in the great plains of North America between 1984 and 2008 (Graybosch and Peterson, 2010) and spring wheat in Chile between 1990 and 2000 (Matus et al., 2012) and in Brazil between 1999 and 2009 (Beche et al., 2014). In addition, Brisson et al. (2010) found genetic progress in yield potential in France had been counteracted from 1990 onward by climate change (particularly by heat stress).

Knowledge of the changes in physiological traits associated with genetic gains in yield potential is essential to improve understanding of yield-limiting factors and to inform future breeding strategies. Studies of the physiological basis of genetic gains in grain yield in sets of historic wheat cultivars worldwide have generally shown number of grains per square meter (usually because of number of grains per spike) and HI to be positively associated with grain yield progress (e.g., Waddington et al., 1986; Sayre et al., 1997; Austin et al., 1989; Slafer et al., 1990; Brancourt-Hulmel et al., 2003). Fischer et al. (1998) reported higher stomatal conductance preanthesis for spring wheats released from 1962 to 1988 in northwest Mexico under fully irrigated conditions and found a positive association between grain yield and grains per square meter and, in one year out of the three, a positive association between crop growth rate (CGR) and radiation-use efficiency (RUE) in the 3-wk period before flowering. Greater light-saturated photosynthetic rate was found in the more recent cultivars. Shearman et al. (2005) found genetic progress in grain yield of UK winter wheat from 1972 to 1995 was from about 1980 onward based mainly on improvement in harvest biomass associated with a higher RUE in the stem-elongation period, driving increases in grains per square meter and stem soluble carbohydrate reserves. Changes in the flag leaf with breeding progress at CIMMYT (e.g., smaller, more erect flag leaves, higher $\mathrm{N}$ per unit area) (Fischer et al., 1998) were similar to those reported for winter wheat progress in the United Kingdom (e.g., smaller, more erect flag leaves, higher DM per unit area) (Shearman et al., 2005). Xiao et al. (2012) reported genetic gain in grain yield of winter wheat released from 1962 to 2006 in Shandong Province, China, was $62 \mathrm{~kg} \mathrm{ha}^{-1} \mathrm{yr}^{-1}$, largely associated with increased grains per square meter and biomass together with increased HI and reduced plant height. Significant genetic changes were also observed for leaf area index (total leaf area per ground area), flag-leaf chlorophyll content, and stem water-soluble carbohydrate (WSC) content at anthesis and flag-leaf photosynthesis rate during grain filling. Similar to the findings of Shearman et al. (2005), increases in grains per square meter and biomass were apparently achieved through improving crop photosynthesis at and after heading, and increased stem WSC in stems at anthesis. Beche et al. (2014) reported genetic gains in grain yield of $29.9 \mathrm{~kg} \mathrm{ha}^{-1} \mathrm{yr}^{-1}$ in spring wheat in Brazil from 1940 to 2009 were associated with gains in HI, biomass, and grains per square meter; and that preand postanthesis stomatal conductance and leaf photosynthesis rate and postanthesis leaf chlorophyll content were positively associated with grain yield. In addition, grainyield progress of CIMMYT advanced lines released from 1977 to 2008 was associated with fewer days to heading, cooler canopy temperature at grain filling, increased stay green, and higher grain weight (Lopes et al., 2012).

Grain yield under optimal conditions appears to be mainly limited by grain number per square meter. In the studies cited above, grain weight was almost always reported not to increase with YoR. A physiological model for analyzing grain number per square meter $(\mathrm{GN})$ was proposed by Fischer (1983):

$$
\mathrm{SDW}_{\mathrm{a}}=D_{\mathrm{s}} \times \mathrm{CGR} \times F_{\mathrm{s}}
$$

where $\mathrm{SDW}_{\mathrm{a}}$ is the dry weight of spikes at anthesis (per unit area basis), $D_{\mathrm{s}}$ is the duration of spike growth, and CGR and $F_{s}$ are, respectively, the rate of aboveground dry accumulation and the fraction of this DM growth partitioned to the spike averaged over the spike-growth period.

In the model of Fischer (1983) also:

$$
\mathrm{GN}=\mathrm{SDW}_{\mathrm{a}} \times \mathrm{FE}
$$

where FE is the fruiting efficiency, defined as the number of grains per unit spike DW at anthesis.

This model will be referred to in the present analysis of the physiological basis of GN among a set of historic CIMMYT semidwarf cultivars introduced from 1966 to 2009. Moreover, the importance of increasing the total grain sink size, not only by increasing grains per square meter but also the PGW, will be considered. In this respect, a degraining treatment (removal of $50 \%$ of the spikelets) was imposed at $14 \mathrm{~d}$ postanthesis (GS61) to study source-sink relationships in the 12 cultivars. Lopes et al. (2012) reported grain yield progress of CIMMYT advanced lines from 1977 to 2008 was associated with increased grain weight as mentioned above. 
The present paper aims to (i) quantify changes in GN, grain weight, HI, and harvest AGDM associated with grain yield progress for a set of 12 representative CIMMYT spring wheat cultivars developed between 1966 and 2009 in the irrigated, high-potential environment of northwest Mexico and (ii) identify the physiological basis of these changes by examining phenology, DM production and partitioning, CGR, flag-leaf traits, and source-sink balance and PGW according to a degraining treatment imposed at GS61 +14 d.

\section{MATERIALS AND METHODS Experimental Site and Design}

Experiments were conducted at the CIMMYT Norman E. Borlaug Experimental Station near Ciudad Obregon, northwest Mexico $\left(20^{\circ} 27^{\prime} \mathrm{N}, 54^{\circ} 109^{\prime} \mathrm{W} ; 38 \mathrm{~m}\right.$ asl) in three seasons (2008-2009, 2009-2010, and 2010-2011; hereafter, referred to as the years 2009, 2010, and 2011, respectively). The site is in an intertropical region and the experiments were performed in highpotential conditions under optimum irrigation (Reynolds et al., 2007). The soil type is coarse sandy clay, mixed montmorillonitic typic calciorthid, low in organic matter $(<1 \%)$ and slightly alkaline ( $\mathrm{pH}$ 7.7) (Limon-Ortega et al., 2002). In each of the experiments, 12 cultivars released from 1966 to 2009 were examined (Table 1). The cultivars were selected because they were the most widely grown CIMMYT releases during the 43-yr period from 1966 to 2009. A randomized complete block design was implemented with four replications. Each plot consisted of two beds, each of which was 4-m long and $0.8-\mathrm{m}$ wide with two rows $30 \mathrm{~cm}$ apart per bed (and two rows $50 \mathrm{~cm}$ apart between beds).

At growth stage (GS) 61 (onset of anthesis) $+14 \mathrm{~d}$ (Tottman, 1987), 15 randomly selected fertile (those with a spike) shoots per plot were tagged and all the spikelets were removed from one side of the spike to determine the effect of degraining on grain weight at harvest in three replicates. Fifteen randomly selected control shoots were also tagged at this stage in the same three replicates.

\section{Plot Management}

The sowing dates were 18 Nov. 2008, 3 Dec. 2009, and 3 Dec. 2010. In each experiment, plots were irrigated using a gravitybased system with flood irrigations four to six times during the crop cycle at 3- to 4-wk intervals to supply adequate moisture to avoid water stress during the growing season. After sowing, four applications of irrigation were made in each of 2009 and 2010 and six applications in 2011. The fertilizer application regime was the same in all seasons. The first application of $\mathrm{N}\left(50 \mathrm{~kg} \mathrm{ha}{ }^{-1}\right)$ was applied as urea during land preparation followed by $40 \mathrm{~kg} \mathrm{ha}^{-1}$ of $\mathrm{P}$ as triple-super $\mathrm{P}$ at sowing. The second application of $\mathrm{N}\left(50 \mathrm{~kg} \mathrm{ha}^{-1}\right)$ as urea was added at the time of first irrigation. Herbicides were applied in each season during early tillering in December as Buctril $\left(1300 \mathrm{~mL} \mathrm{ha}^{-1}\right.$; Bayer Crop Science) for broad-leaf weeds and Axial $(500 \mathrm{~mL}$ $\mathrm{ha}^{-1}$; Syngenta) for narrow-leaf weeds. In each season, a fungicide application as Folicur $\left(500 \mathrm{~mL} \mathrm{ha}^{-1}\right.$; Bayer Crop Science) was applied four times from approximately onset of stem extension to early grain filling during January to March. Insecticides
Table 1. Year of release, the presence of $R h t-B 1 b$ and $R h t-D 1 b$ semidwarfing genes, and the $1 B L / 1 R S$ translocation for 12 CIMMYT spring wheat cultivars released from 1966 to 2009.

\begin{tabular}{lccc}
\hline \multicolumn{1}{c}{ Genotype } & $\begin{array}{c}\text { Year of } \\
\text { release }\end{array}$ & $\begin{array}{c}\text { Rht } \\
\text { semidwarfing } \\
\text { genes }\end{array}$ & $\begin{array}{c}\text { Presence } \\
\text { of 1BL/1RS } \\
\text { translocation }\end{array}$ \\
\hline Siete Cerros & 1966 & $R h t-B 1 b$ & No \\
Pavon & 1976 & $R h t-D 1 b$ & No \\
Seri & 1982 & $R h t-B 1 b$ & Yes \\
Bacanora & 1988 & $R h t-B 1 b$ & Yes \\
Attila (PBW 343) & 1990 & $R h t-B 1 b$ & Yes \\
Baviacora & 1992 & $R h t-B 1 b$ & Mixed \\
Tarachi & 2000 & $R h t-B 1 b$ & No \\
Tacupeto & 2001 & $R h t-B 1 b$ & No \\
Roelfs & 2007 & $R h t-B 1 b$ & No \\
Navojoa & 2007 & $R h t-B 1 b$ & No \\
Becard & 2009 & $R h t-B 1 b$ & No \\
Line 1 ${ }^{\dagger}$ & 2009 & N/A $\neq$ & N/A \\
\hline
\end{tabular}

† Pedigree: Croc_1/Ae Squarrosa (205)//Borl95/3/Prl/Sara/Tsi/Vee\#5/4/Fret2.

‡N/A, data not available.

as Aflix (1 $\mathrm{L} \mathrm{ha}^{-1}$; Sandoz) and Lorsban $\left(1400 \mathrm{~mL} \mathrm{ha}^{-1}\right.$; Dow AgroSciences) were applied in each season at around early- to mid stem extension during January to February.

\section{Crop Measurements Crop Growth Analysis}

Dates of onset of stem extension (GS31; growth stage 31), flag-leaf emergence (GS39), anthesis (GS61) (Tottman, 1987), and CCS (when 50\% of the shoots had no flag leaf or spike green area and less than $10 \%$ of the stem remained green) were recorded in each plot of three replicates in all years. In 2009 and 2010, growth of the aboveground plant material was analyzed at GS31 (in each plot of two replicates in 2009 and of three replicates in 2010) and at GS61 $+7 \mathrm{~d}$ (in each plot of three replicates in 2009 and 2010). In each case, plant material was sampled in two 50-cm-length rows of the bed $\left(0.4 \mathrm{~m}^{2}\right)$, situated at least 50 $\mathrm{cm}$ from the end of the plot. Genotypes were sampled on the actual calendar dates that they reached the specific stage, that is, genotypes were sampled on different dates. At GS31, plants were counted in the $0.5 \times 0.8 \mathrm{~m}$ quadrat area before sampling.

At GS31 and GS61 +7 d, plants were cut off at ground level and the number of fertile and infertile shoots was counted. At GS31, infertile shoots were classified as those that either had no green area or for which the newest fully expanded leaf was completely senesced; the remaining shoots were classified as fertile. At GS61 +7 d, fertile shoots were classified as those with a spike; the remaining shoots were classified as infertile. The weight of the infertile shoots was recorded after drying for $48 \mathrm{~h}$ at $75^{\circ} \mathrm{C}$. A subsample of 15 fertile shoots was taken by fresh weight and separated into (i) spikes, (ii) flag-leaf lamina, (iii) remaining lamina, and (iv) stem with attached leaf sheath, depending on the developmental stage. Dry matter of crop components (leaf lamina, stem and leaf sheath, etc.) was obtained by weighing components of the 15-shoot subsample after drying for $48 \mathrm{~h}$ at $75^{\circ} \mathrm{C}$.

In 2009 and 2010, rachis length and spikelet number per spike were recorded on 12 randomly selected spikes per plot at GS61 +7 $d$ in three replicates. Percentage WSC concentration in 
stems and attached leaf sheaths was estimated at GS61 +7 d and at maturity in 10 randomly selected fertile shoots per plot in three replicates, using the anthrone method of Yemm and Willis (1954) as described by Gay et al. (1998). In relation to the grain number model of Fischer (1983), the spike-growth period was presently estimated as onset of stem extension (GS31, Tottman, 1987) to anthesis (GS61) +7 d. The CGR was calculated as the accumulated AGDM from GS31 to GS61 +7 d divided by the number of calendar days for this period. The spike-partitioning index (SPI) was calculated as the ratio of the spike DM to the fertile-shoot DM at GS61 +7 d. The FE was calculated as the number of grains per unit spike dry weight at GS61 +7 d.

At harvest, the 15 tagged degrained shoots (i.e., 50\% spikelets removed) and 15 tagged control shoots were sampled in each plot. The spikes were then threshed and their grains counted and weighed after drying for $48 \mathrm{~h}$ at $75^{\circ} \mathrm{C}$. The dry weight of the stem and the attached leaf sheaths was also weighed after drying for $48 \mathrm{~h}$ at $75^{\circ} \mathrm{C}$.

In each experiment, after maturity was reached, grain yield was measured by machine harvesting a plot area of $4.8 \mathrm{~m}^{2}$ in each plot in four replicates and values adjusted to $0 \%$ moisture content. Before machine harvesting, 100 spike-bearing shoots were removed from each plot and the plant material was dried for $48 \mathrm{~h}$ at $75^{\circ} \mathrm{C}$ and weighed, and the spikes were then threshed. Dry weight of grains from 100 spikes was recorded. From this lot, 200 grains were randomly counted and weighed to determine the 1000-grain weight (TGW). The grains per spike (GPS) was calculated by dividing the grain weight per shoot (g) by the TGW(g)/1000. The spikes per square meter was then calculated by dividing the machine-harvested grain yield $\left(\mathrm{g} \mathrm{m}^{-2}\right.$ ) (from $4.8 \mathrm{~m}^{2}$ area) by the product of GPS and TGW(g)/1000. Finally, aboveground biomass was calculated by dividing the machine-harvested grain yield (from $4.8 \mathrm{~m}^{2}$ area) by the HI (from the 100-shoot sample).

\section{Stomatal Conductance and Canopy Temperature Depression}

In 2010, stomatal conductance was measured using the Decagon SC-1 Leaf Porometer (Decagon Devices, Inc.) approximately weekly from flag-leaf emergence (GS39) until mid-to-late grain filling in each plot of three replicates; there were two measurements preanthesis and five measurements in the $30 \mathrm{~d}$ postanthesis. Measurements were taken on the middle of the adaxial surface of the flag leaf, which was fully exposed to the sunlight for four leaves per plot from 11:00 to $15: 00$ on clear, sunny days. In 2009 and 2010, canopy temperature was determined by using a hand-held (Sixth Sense LT300) infrared thermometer (Total Temperature Instrumentation, Inc.) in each plot of three replicates. Readings were taken at an angle of approximately $30^{\circ}$ to the horizontal approximately $0.5 \mathrm{~m}$ above the canopy. Two readings per plot were made around midday during cloudless periods. In the preanthesis period, there were two measurements from GS39 to GS61 in each year, and in the postanthesis period, there were two measurements in 2009 (approximately 20 and 30 $\mathrm{d}$ post-GS61), and one measurement in 2010 (approximately 20 d post-GS61). Air temperature was measured at the same time as the canopy temperature and canopy temperature depression (CTD) was calculated as follows:

$$
\mathrm{CTD}=T_{\mathrm{a}}-T_{\mathrm{c}}
$$

where $T_{a}$ is the air temperature and $T_{c}$ is the canopy temperature.

\section{Statistical Analysis}

Standard analysis of variance (ANOVA) procedures were used to calculate treatment means, standard errors, and significant differences between treatments using the GenStat program (VSN International, 2010). The significance of the treatment effects was determined by ANOVA including year as random and cultivar as fixed main effect, and their interactions. Treatment means were compared using the LSD of the means of Fisher, calculated from standard errors of the difference of the means using appropriate degrees of freedom, when the ANOVA indicated significant differences. For ANOVAs across years, Bartlett's test $(P=0.05)$ was used to test for the homogeneity of variances, and years were regarded as random effects. The mean square for the year effect was tested against an error $A$ mean square representing the variation between blocks. The mean square of the cultivar and year effects was tested against an error $B$ mean square representing residual variation. Treatment means were compared using the LSD.

Where the effect of cultivar was statistically significant, associations between traits and between traits and grain yield among cultivars were examined through correlation, regression (linear and nonlinear), and multivariate biplot analysis procedures based on the cultivar mean values across years using the GenStat program.

\section{RESULTS \\ Development, Plant Height, and Plant Establishment}

Cultivar ranges averaging over years for dates of onset of stem extension (GS31), anthesis (GS61), and CCS were 8,10, and $7 \mathrm{~d}$, respectively (Table 2 ). The year $\times$ cultivar interaction was not statistically significant for any of the growth stages (data not shown) (Table 2). There was no change in date of GS31 with YoR. There was a nonlinear change in date of GS61 with YoR; days from sowing to GS61 increased up to approximately 1980 and then decreased (quadratic $R^{2}$ $=0.73, P<0.03$; Table 2). There was a linear change in date of CCS with YoR, with days from sowing to CCS overall increasing by $5 \mathrm{~d}$ over the 43 -yr period $\left(R^{2}=0.37\right.$, $P<0.05)$. The duration of GS61 to CCS initially decreased to approximately 1980 and then increased with an overall increase of $4 \mathrm{~d}$ across the 43-yr period (quadratic $R^{2}=0.67$, $P=0.07)$. There was no systematic change in the duration from sowing to GS31 or for the stem-elongation phase (GS31-GS61) with plant breeding. Averaging over years, plant height ranged from 89.4 to $109.6 \mathrm{~cm}$ among the cultivars $(P<0.001$; Table 2$)$ and increased linearly by $0.25 \mathrm{~cm}$ $\mathrm{yr}^{-1}$ with $\operatorname{YoR}\left(R^{2}=0.37, P<0.05\right)$. 
Table 2. Number of days after sowing to growth stages (GS) 31 and 61 and complete canopy senescence (CCS), days for phenophases, and plant height and plants per $\mathrm{m}^{2}$ for 12 CIMMYT spring wheat cultivars. Values for dates of growth stages and phenophase durations represent means in 2009 and 2010. Values for plant height and plants per $\mathrm{m}^{2}$ represent means in 2009 , 2010, and 2011.

\begin{tabular}{|c|c|c|c|c|c|c|c|}
\hline $\begin{array}{c}\text { Cultivar } \\
\text { (year of release) }\end{array}$ & GS31 & GS61 & $\begin{array}{c}\text { Days from } \\
\text { GS31 to GS61 }\end{array}$ & CCS & $\begin{array}{l}\text { Days from } \\
\text { GS61 to CCS }\end{array}$ & Plant height & Plants per $\mathrm{m}^{2}$ \\
\hline & & & $-d-$ & & & $\mathrm{cm}$ & \\
\hline Siete Cerros (1966) & 46.0 & 84.5 & 38.5 & 135.0 & 50.5 & 93.8 & 172.8 \\
\hline Pavon (1976) & 48.0 & 90.5 & 42.5 & 139.5 & 49.0 & 101.0 & 185.5 \\
\hline Seri (1982) & 48.0 & 91.5 & 43.5 & 137.5 & 46.0 & 90.8 & 176.7 \\
\hline Bacanora (1988) & 53.5 & 91.5 & 38.0 & 136.0 & 44.5 & 89.4 & 139.2 \\
\hline Attila (1990) & 47.0 & 94.0 & 47.0 & 137.0 & 43.0 & 99.3 & 183.0 \\
\hline Baviacora (1992) & 48.5 & 91.5 & 43.0 & 142.0 & 50.5 & 103.8 & 202.3 \\
\hline Tarachi (2000) & 49.5 & 90.5 & 41.0 & 138.5 & 48.0 & 99.1 & 182.5 \\
\hline Tacupeto (2001) & 47.5 & 91.5 & 44.0 & 140.0 & 48.5 & 99.5 & 196.4 \\
\hline Roelfs (2007) & 46.0 & 87.5 & 41.5 & 138.0 & 50.5 & 109.6 & 174.7 \\
\hline Navojoa (2007) & 46.5 & 92.5 & 46.0 & 142.0 & 49.5 & 103.8 & 199.4 \\
\hline Becard (2009) & 51.0 & 86.5 & 35.5 & 140.5 & 54.0 & 101.2 & 179.4 \\
\hline Line 1 (2009) & 45.0 & 85.5 & 40.5 & 140.5 & 55.0 & 101.4 & 181.4 \\
\hline $\mathrm{SED}^{\dagger}$ (cultivar) & 1.32 & 0.83 & 1.52 & 0.38 & 0.88 & 1.16 & 12.84 \\
\hline df & 44 & 44 & 44 & 44 & 44 & 66 & 66 \\
\hline
\end{tabular}

† SED, standard error of the differences.

Table 3. Grain yield, harvest aboveground dry matter (AGDM), harvest index, spikes per $\mathrm{m}^{2}$, grains per spike, grains per $\mathrm{m}^{2}$, and grain weight for 12 CIMMYT spring wheat cultivars released from 1966 and 2009. Values represent means in 2009, 2010, and 2011

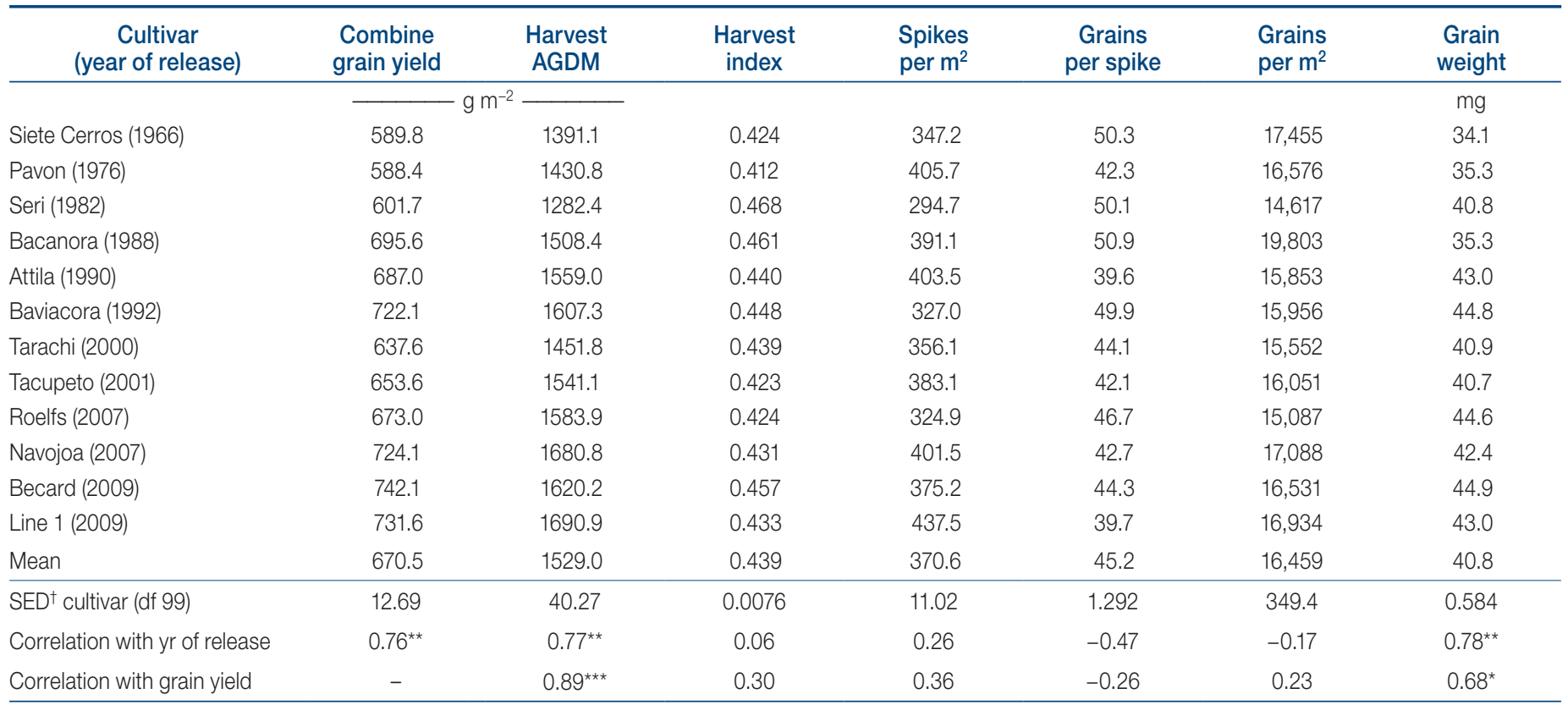

* Significant at the 0.05 probability level.

${ }^{* *}$ Significant at the 0.01 probability level.

${ }^{* * *}$ Significant at the 0.001 probability level.

† SED, standard error of the differences.

Averaging over years, plants per square meter ranged from 139 to $202(P<0.05$; Table 2$)$. Among 11 of the 12 cultivars, there were no significant differences in the range 177 to 202 plants $\mathrm{m}^{-2}$. Bacanora at 139 plants $\mathrm{m}^{-2}$ had fewer plants per square meter than several other cultivars. There was no significant association between plants per square meter and either spikes per square meter at harvest $\left(R^{2}=0.04\right)$ or grain yield $\left(R^{2}=0.02\right)$ within the 12 cultivars (Table 3 ).

\section{Grain Yield and Yield Components}

Grain yield ranged from 588 to $742 \mathrm{~g} \mathrm{~m}^{-2}$ among cultivars $(P<0.001$; Table 3; Fig. 1$)$, and the year $\times$ cultivar interaction was not statistically significant (data not shown). There was a linear genetic gain in grain yield of $0.030 \mathrm{t}$ $\mathrm{ha}^{-1} \mathrm{yr}^{-1}\left(0.59 \% \mathrm{yr}^{-1}\right.$, relative to grain yield in $1966 ; R^{2}$ $=0.58, P<0.001$; Table 4; Fig. 1). Overall, grains per square meter ranged from 14,607 to $19,803(P<0.001)$ 
a )

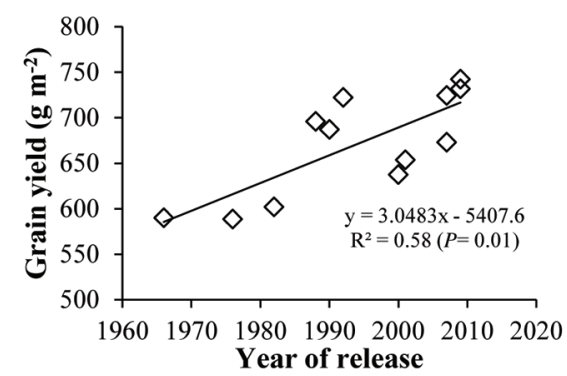

d)

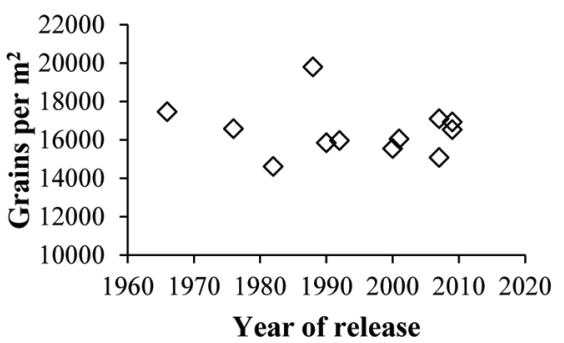

b )

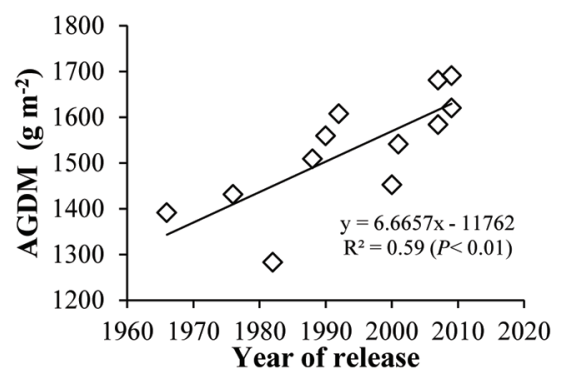

e)

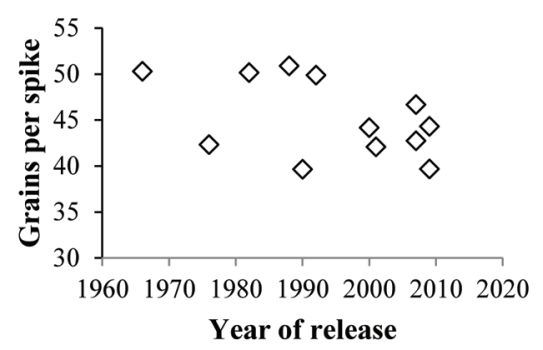

c)

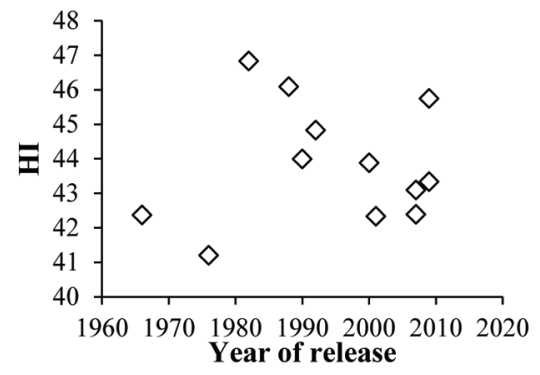

f)

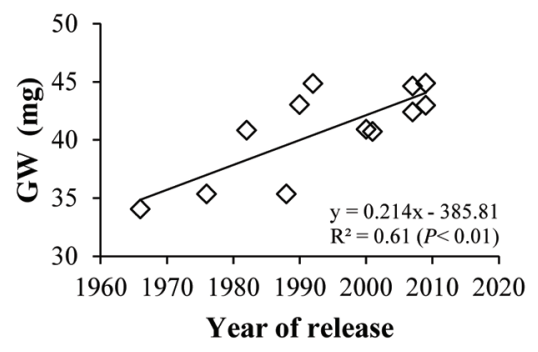

Figure 1. Regression of year of release on (a) grain yield ( $0 \%$ moisture content), (b) aboveground dry matter (AGDM) at harvest, (c) harvest index (HI, \%), (d) grains per $\mathrm{m}^{2}$, (e) grains per spike, and (f) grain weight (GW, 0\% moisture content) for 12 CIMMYT spring wheat cultivars released from 1966 to 2009. Values represent mean of 2009, 2010, and 2011.

Table 4. Fitted parameter estimates for linear changes in crop traits with year of release for 12 CIMMYT spring wheat cultivars released from 1966 and 2009. Linear function $(y=a$ $+b x)$ was fitted to 3-yr cultivar means $(2009,2010$, and 2011).

\begin{tabular}{|c|c|c|}
\hline \multirow[b]{2}{*}{ Trait } & \multicolumn{2}{|c|}{$\begin{array}{l}\text { Parameter estimates } \\
\qquad(y=a+b x)\end{array}$} \\
\hline & $y$ (as in 1966) & $b \pm \mathrm{SE}$ \\
\hline \multicolumn{3}{|l|}{ Yield and yield components } \\
\hline Combine grain yield, $\mathrm{g} \mathrm{m}^{-2}$ & 589.8 & $3.048 \pm 0.813^{* *}$ \\
\hline Grains per $\mathrm{m}^{2}$ & $17,455.1$ & $-15.7 \pm 29.6 \mathrm{~ns}^{\ddagger}$ \\
\hline Spikes per $\mathrm{m}^{2}$ & 347.2 & $0.755 \pm 0.899 \mathrm{~ns}$ \\
\hline Grains per spike & 50.3 & $-0.1412 \pm 0.0830 \mathrm{~ns}$ \\
\hline Grain weight, mg & 34.1 & $0.2140 \pm 0.0545^{\star \star}$ \\
\hline \multicolumn{3}{|l|}{$\mathrm{AGDM}$ and $\mathrm{HI}^{\dagger}$} \\
\hline AGDM harvest, $\mathrm{g} \mathrm{m}^{-2}$ & 1391.1 & $6.67 \pm 1.75^{\star \star}$ \\
\hline $\mathrm{HI}, \%$ & 42.4 & $0.0086 \pm 0.0388 n s$ \\
\hline $\begin{array}{l}\text { Plant height, } \mathrm{cm} \\
\mathrm{df}\end{array}$ & 93.8 & $\begin{array}{c}0.243 \pm 0.102^{*} \\
10\end{array}$ \\
\hline
\end{tabular}

* Significant at the 0.05 probability level.

** Significant at the 0.01 probability level.

${ }^{\dagger}$ AGDM, aboveground dry matter; $\mathrm{HI}$, harvest index.

${ }^{\ddagger}$ ns, not significant.

among cultivars, but there was no association with YoR. Similarly spikes per square meter and grains per spike ranged from 295 to $437 \mathrm{~m}^{-2}(P<0.001)$ and 39.6 to 50.1 $(P<0.001)$, respectively, among cultivars, but there were no associations with YoR (Table 3 and Table 4). Grain weight ranged from 34.1 to $44.9 \mathrm{mg}$ among cultivars and was linearly positively associated with YoR $\left(R^{2}=0.61, P\right.$ $<0.01$; Table 3; Fig. 1). Averaging over years, there was a positive linear association between grain yield and grain weight among cultivars $\left(R^{2}=0.46, P<0.05\right)$, whereas there was no significant association between grain yield and grains per square meter.

Overall, AGDM ranged from 1282 to $1691 \mathrm{~g} \mathrm{~m}^{-2}$ among the cultivars $(P<0.001$; Table 3$)$ and increased linearly with YoR over the 43 -yr period by $6.67 \mathrm{~g} \mathrm{~m}^{-2}$ $\mathrm{yr}^{-1}\left(R^{2}=0.59, P<0.01\right.$; Table 3, 4; Fig. 2$)$; the year $\times$ cultivar interaction was not statistically significant (data not shown). Grain yield $\left(R^{2}=0.80, P<0.001\right)$ and plant height $\left(R^{2}=0.48, P<0.05\right)$ were each positively linearly associated with AGDM. Overall HI ranged among the cultivars from 0.41 to 0.47 and a nonlinear (quadratic) relationship was found between grain yield and HI over the 43-yr period $(P<0.001$; Table 3; Fig. 1,2$)$. Grain yield increased with HI up to values of $\sim 0.45$ and then decreased slightly at higher values of HI. There was a trend for a negative linear association among the genotypes between plant height and HI $\left(R^{2}=0.27 ; P=0.08\right)$.

\section{Dry Matter Production and Partitioning at Anthesis and Crop Growth Rate}

Averaging across 2009 and 2010, there was a weak trend for a linear increase in AGDM at GS61 $+7 \mathrm{~d}$ with YoR $\left(R^{2}\right.$ $=0.23, P=0.11$; Table 5$)$. There was a positive linear association between plant height and AGDM at GS61 $+7 \mathrm{~d}\left(R^{2}\right.$ $=0.34, P<0.05)$. Nonlinear changes in DM partitioning indices with YoR were observed. Spike partitioning index increased from 1966 up to approximately 1980 and then decreased to 2009 (quadratic; $R^{2}=0.48 ; P=0.085$ ); there was a small decrease in SPI from 0.25 to 0.23 over the $43-y r$ period (Table 5). There was a negative linear association between plant height and SPI $\left(R^{2}=0.42 ; P<0.05\right)$. Stem-and-leaf-sheath partitioning index increased mainly 
b )

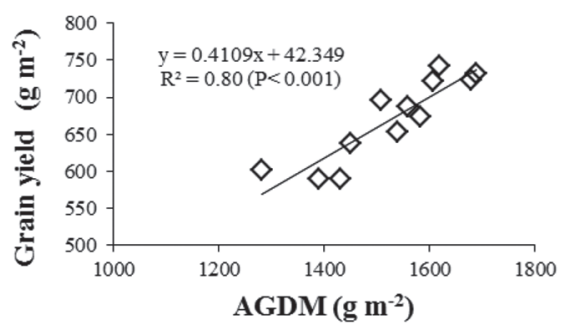

d)

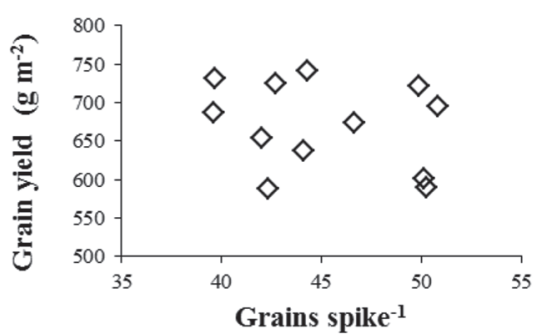

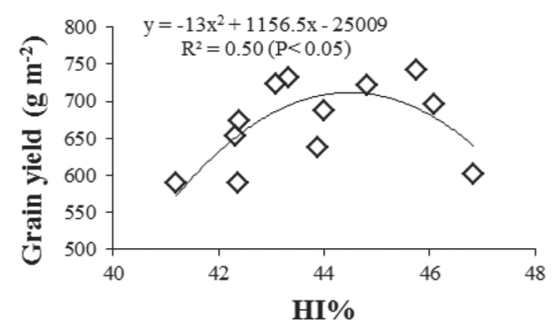

e)

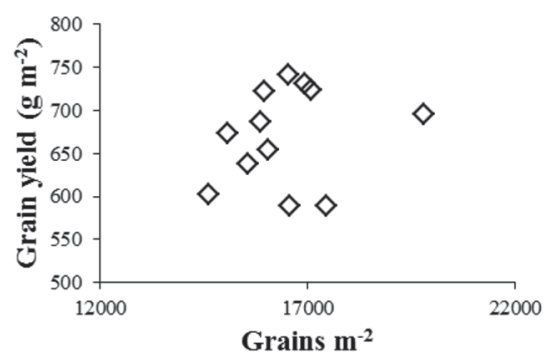

c)

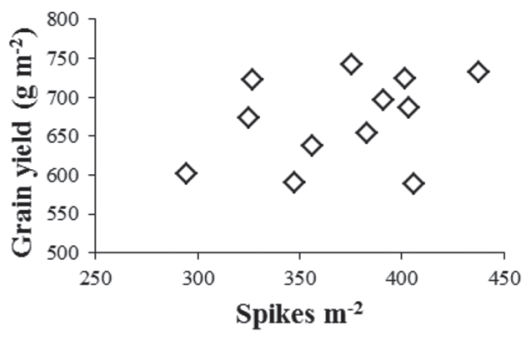

f)

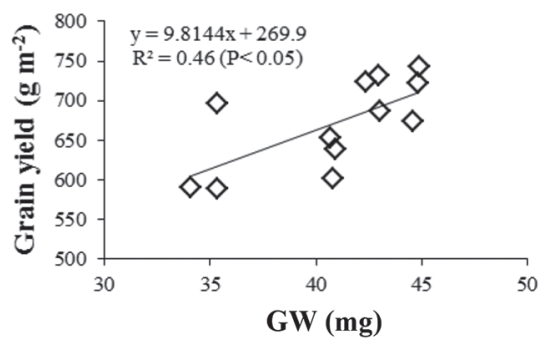

Figure 2. Regression of grain yield (0\% moisture content) on (a) aboveground dry matter (AGDM) at harvest , (b) harvest index (HI, \%), (c) spikes per $\mathrm{m}^{2}$, (d) grains per spike, (e) grains per $\mathrm{m}^{2}$, and (f) grain weight (GW) for 12 CIMMYT spring wheat cultivars released from 1966 to 2009. Values represent mean of 2009, 2010, and 2011.

Table 5. Fertile and infertile shoots dry matter (DM), spike DM, spike-partitioning index, fruiting efficiency, stem-and-leafsheath DM, stem-and-leaf-sheath partitioning index, lamina DM, and lamina partitioning index at GS61 +7 d for 12 CIMMYT spring wheat cultivars released from 1966 to 2009. Values represent means in 2009 and 2010.

\begin{tabular}{|c|c|c|c|c|c|c|c|c|c|}
\hline $\begin{array}{c}\text { Cultivar } \\
\text { (year of release) }\end{array}$ & $\begin{array}{c}\text { Fertile } \\
\text { shoots } \\
\text { DM }\end{array}$ & $\begin{array}{c}\text { Infertile } \\
\text { shoots } \\
\text { DM }\end{array}$ & $\begin{array}{l}\text { Spike } \\
\text { DM }\end{array}$ & $\begin{array}{c}\text { Spike } \\
\text { partitioning } \\
\text { index }^{\ddagger}\end{array}$ & $\begin{array}{l}\text { Fruiting } \\
\text { efficiency }\end{array}$ & $\begin{array}{c}\text { Stem } \\
\text { DM }\end{array}$ & $\begin{array}{l}\text { Stem } \\
\text { partitioning } \\
\text { index }\end{array}$ & $\underset{\text { DM }}{\text { Lamina }}$ & $\begin{array}{l}\text { Lamina } \\
\text { partitioning } \\
\text { index }\end{array}$ \\
\hline & - & $-\mathrm{g} \mathrm{m}^{-2}$ & 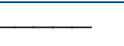 & & grains $\mathrm{g}^{-1}$ & $\mathrm{~g} \mathrm{~m}^{-2}$ & & $\mathrm{~g} \mathrm{~m}^{-2}$ & \\
\hline Siete Cerros (1966) & 757.3 & 33.9 & 188.7 & 0.249 & 100.6 & 404.6 & 0.534 & 164.0 & 0.217 \\
\hline Pavon (1976) & 980.5 & 37.8 & 262.8 & 0.269 & 70.0 & 510.2 & 0.521 & 207.5 & 0.210 \\
\hline Seri (1982) & 831.0 & 29.9 & 232.3 & 0.282 & 67.3 & 432.6 & 0.520 & 166.2 & 0.198 \\
\hline Bacanora (1988) & 863.2 & 36.3 & 231.1 & 0.268 & 92.1 & 462.9 & 0.536 & 169.2 & 0.196 \\
\hline Attila (1990) & 891.5 & 27.0 & 234.6 & 0.262 & 72.7 & 495.1 & 0.556 & 161.9 & 0.182 \\
\hline Baviacora (1992) & 823.2 & 32.9 & 201.0 & 0.244 & 85.6 & 449.1 & 0.546 & 173.1 & 0.210 \\
\hline Tarachi (2000) & 814.9 & 30.1 & 217.3 & 0.268 & 77.1 & 445.3 & 0.546 & 152.3 & 0.186 \\
\hline Tacupeto (2001) & 939.4 & 31.6 & 267.5 & 0.284 & 66.1 & 492.8 & 0.524 & 179.1 & 0.191 \\
\hline Roelfs (2007) & 1001.8 & 36.8 & 213.7 & 0.214 & 77.1 & 571.8 & 0.571 & 216.3 & 0.215 \\
\hline Navojoa (2007) & 1000.7 & 29.8 & 256.2 & 0.256 & 71.0 & 566.1 & 0.566 & 178.3 & 0.178 \\
\hline Becard (2009) & 967.4 & 46.6 & 229.9 & 0.239 & 79.3 & 547.9 & 0.564 & 189.6 & 0.197 \\
\hline Line 1 (2009) & 834.9 & 25.8 & 195.0 & 0.233 & 93.0 & 467.8 & 0.560 & 172.1 & 0.207 \\
\hline Mean & 892.1 & 33.2 & 227.5 & 0.256 & 79.3 & 487.2 & 0.545 & 177.4 & 0.199 \\
\hline$\overline{\text { SED }^{\dagger} \text { cultivar (df 44) }}$ & $48.68^{\star \star \star}$ & $7.39 \mathrm{~ns}^{\S}$ & $14.58^{\star \star \star}$ & $0.0087^{* \star \star}$ & $5.62^{\star \star \star}$ & $28.28^{\star \star \star}$ & $0.0106^{\star \star \star}$ & $12.86^{* \star \star}$ & $0.0072^{\star \star \star}$ \\
\hline Correlation (yr of release) & 0.48 & 0.01 & 0.09 & -0.41 & -0.22 & $0.64^{\star}$ & $0.72^{\star \star}$ & 0.20 & -0.37 \\
\hline Correlation (grain yield) & 0.29 & 0.10 & -0.12 & $-0.50^{\natural}$ & 0.14 & 0.48 & $0.74^{\star *}$ & 0.07 & -0.25 \\
\hline
\end{tabular}

* Significant at the 0.05 probability level.

** Significant at the 0.01 probability level.

*** Significant at the 0.001 probability level.

+ SED, standard error of the differences.

‡ Partitioning indices for spike, stem, and lamina calculated as a proportion of the fertile shoots DM.

$\S \mathrm{ns}$, not significant.

" Significant at the 0.10 probability level. 
Table 6. Crop growth rate (CGR) from GS31 to GS61 +7 d and stem-and-leaf-sheath water soluble carbohydrate (WSC) DM at GS61 +7 d for 12 CIMMYT spring wheat cultivars released from 1966 to 2009. Values represent means in 2009 and 2010.

\begin{tabular}{lcc}
\hline $\begin{array}{c}\text { Cultivar } \\
\text { (year of release) }\end{array}$ & $\begin{array}{c}\text { CGR GS31 to } \\
\text { GS61 +7 d }\end{array}$ & $\begin{array}{c}\text { Stem WSC } \\
\text { GS61 +7 d }\end{array}$ \\
\hline Siete Cerros (1966) & $\mathrm{g} \mathrm{m}^{-2} \mathrm{~d}^{-1}$ & $\mathrm{~g} \mathrm{~m}^{-2}$ \\
Pavon (1976) & 17.0 & 53.1 \\
Seri (1982) & 20.2 & 72.1 \\
Bacanora (1988) & 16.6 & 95.6 \\
Attila (1990) & 21.0 & 96.8 \\
Baviacora (1992) & 16.1 & 114.0 \\
Tarachi (2000) & 16.6 & 69.2 \\
Tacupeto (2001) & 16.4 & 96.9 \\
Roelfs (2007) & 18.1 & 96.5 \\
Navojoa (2007) & 20.4 & 70.7 \\
Becard (2009) & 18.9 & 106.8 \\
Line 1 (2009) & 24.4 & 67.0 \\
Mean & 17.1 & 52.6 \\
\hline SED ${ }^{\dagger}$ cultivar (df) & 19.7 & 82.6 \\
Correlation (yr of release) & $1.29^{\star \star * *}(33)$ & $9.76^{\star \star * ~}(44)$ \\
Correlation (grain yield) & 0.30 & 0.10 \\
\hline
\end{tabular}

*** Significant at the 0.001 probability level.

† SED, standard error of the differences.

after approximately 1980 with an overall increase from 0.53 to 0.56 over the $43-\mathrm{yr}$ period (quadratic $R^{2}=0.60$, $P<0.01)$ and was positively linearly associated with plant height among the cultivars $\left(R^{2}=0.43, P<0.05\right)$. There was no change in leaf lamina partitioning index with YoR. The overall effect of the changes in AGDM and DM partitioning was that spike DM at GS61 $+7 \mathrm{~d}$ differed among cultivars in the range 188.7 to $267.5 \mathrm{~g} \mathrm{~m}^{-2}(P<0.001)$; there was no change in spike DM per square meter at GS61 $+7 \mathrm{~d}$ with YoR. Grains per square meter was not associated with spike DM per square meter among the 12 cultivars but showed a positive linear association with the $\mathrm{FE}\left(R^{2}\right.$ $=0.34 ; P<0.05)$, which ranged among the cultivars from 66.1 to 100.6 grains $^{-1}(P<0.001$; Table 5). However, there was no change in the FE with YoR.

Averaging over 2009 and 2010, CGR during the stem-extension phase differed among cultivars in the range 16.6 to $24.4 \mathrm{~g} \mathrm{~m}^{-2} \mathrm{~d}^{-1}(P<0.01$; Table 6$)$. Aboveground DM accumulated during stem extension was not associated with the number of days from GS31 to GS61 $+7 \mathrm{~d}$ but was positively linearly associated with the CGR from GS31 to GS61 $+7 \mathrm{~d}\left(R^{2}=0.53, P<0.05\right)$. Crop growth rate during stem extension also showed a positive linear association with AGDM at GS61 $+7 \mathrm{~d}$ among the cultivars $\left(R^{2}=0.53 ; P<0.05\right)$.

There was a nonlinear change in stem WSC at GS61 $+7 \mathrm{~d}$ per square meter with YoR with the amount of stem WSC increasing from 1966 to approximately 1990 and then decreasing to 2009 (quadratic, $R^{2}=0.46, P=0.06$;
Table 6); overall stem WSC per square meter changed little over the 43-yr period. A similar quadratic regression between the amount stem WSC remobilized to the grain (difference between stem WSC at GS61 $+7 \mathrm{~d}$ and maturity) and YoR was observed (data not shown; mean 65.9 $\mathrm{g} \mathrm{m}^{-2}$; genetic range $\left.30.4-83.7 \mathrm{~g} \mathrm{~m}^{-2}\right)$. Differences in the amount of stem WSC at GS61 $+7 \mathrm{~d}$ among cultivars were associated with stem WSC $\%$ at GS61 $+7 \mathrm{~d}\left(R^{2}=0.69 ; P\right.$ $<0.01$; data not shown; mean $17.1 \%$; genetic range $11.2-$ $23.0 \%)$ and not stem DM per unit area $\left(\mathrm{g} \mathrm{m}^{-2}\right)\left(R^{2}=0.11\right.$; $P=0.30)$ (Table 5).

\section{Leaf and Canopy Traits}

In 2010, preanthesis stomatal conductance differed among cultivars in the range 162 to $294 \mathrm{mmol} \mathrm{m}^{-2} \mathrm{~s}^{-1}(P<0.001)$. There was a strong trend for preanthesis stomatal conductance to increase linearly with YoR among the cultivars $\left(R^{2}=0.32 ; P=0.06\right)$ and a positive linear association between preanthesis stomatal conductance and grain yield $\left(R^{2}=0.48 ; P<0.05\right)$. No associations were found between postanthesis stomatal conductance and either YoR or grain yield. Averaging over 2009 and 2010, CTD during the postanthesis period increased linearly with YoR among cultivars $\left(R^{2}=0.33, P=0.05\right)$ and there was a positive linear association among the cultivars with grain yield $\left(R^{2}=0.66, P<0.001\right.$, Fig. 3$)$ and grain weight $\left(R^{2}\right.$ $=0.27, P=0.08)$. Associations between preanthesis CTD and YoR and grain yield, however, were not statistically significant. The duration of canopy senescence from GS61 to CCS increased by $4 \mathrm{~d}$ over the 43 -yr period; there was a nonlinear change in senescence duration with YoR (quadratic $R^{2}=0.64, P<0.05$ ), with senescence duration increasing from approximately 1980. Overall, grain yield and grain weight were not associated with senescence duration among the 12 cultivars; although, among the 10 cultivars released since 1982, there was a trend for a positive linear association between each of grain yield $\left(R^{2}=0.32, P=0.08\right)$ and grain weight $\left(R^{2}=0.36, P=\right.$ $0.06)$ and senescence duration.

\section{Spike Traits}

Averaging across 2009 and 2010, rachis length ranged among cultivars from 10.8 to $13.9 \mathrm{~cm}(P<0.001)$ but was not associated with YoR (Fig. 4). Fertile spikelets per spike ranged from 16.8 to $21.9(P<0.001)$ and initially increased with breeding but then decreased from approximately 1990 (Fig. 4b) (quadratic $R^{2}=0.58 ; P<0.05$ ). Rachis length was not associated with either fertile spikelets per spike or grain yield among cultivars. However, there was a trend for rachis length per fertile spikelet to increase linearly with $\operatorname{YoR}\left(R^{2}=0.27 ; P=0.08\right)$ (Fig. $\left.4 b\right)$, and this trait was positively linearly associated with grain weight among cultivars $\left(R^{2}=0.46 ; P<0.05\right)$ (Fig. $4 \mathrm{c}$ ). 
a) Pre-anthesis
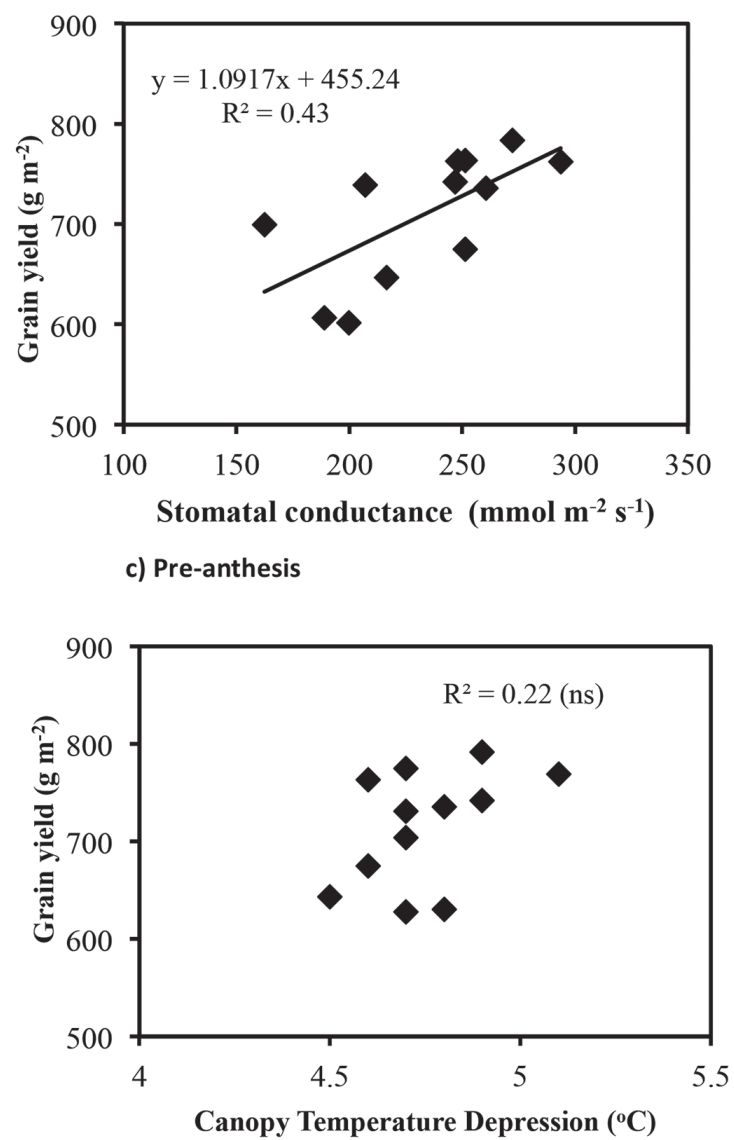

b) Post-anthesis

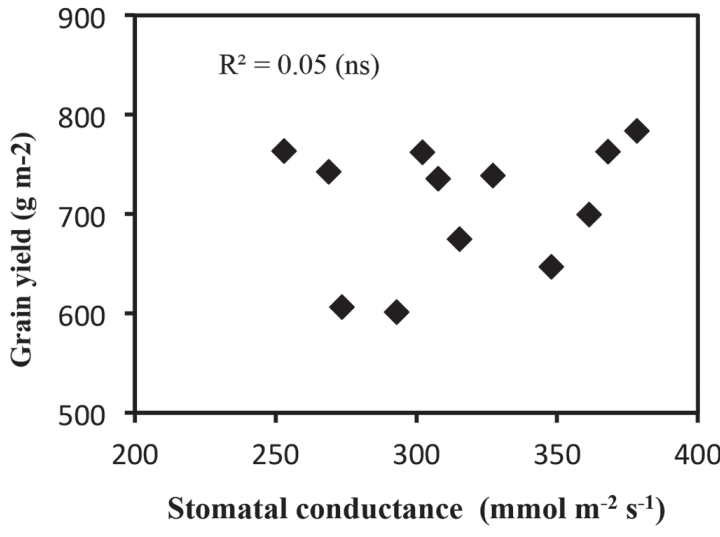

d) Post-anthesis

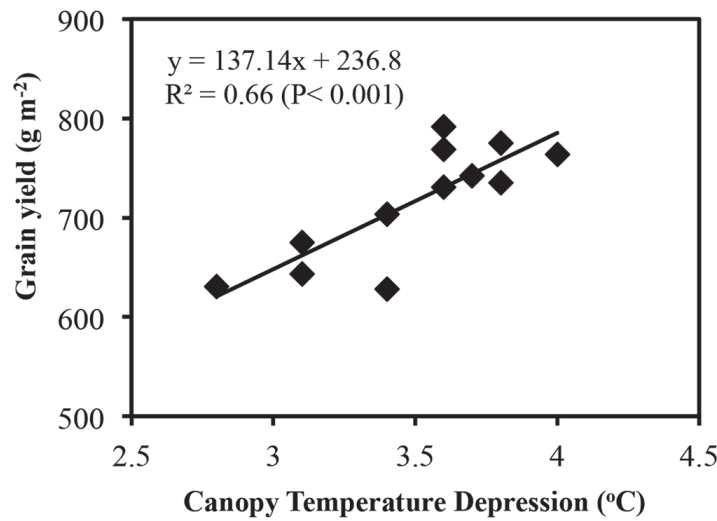

Figure 3. Linear regression of (a) grain yield on preanthesis flag-leaf stomatal conductance, (b) grain yield on postanthesis flag-leaf stomatal conductance, (c) grain yield on preanthesis canopy temperature depression, and (d) grain yield on postanthesis canopy temperature depression for 12 CIMMYT spring wheat cultivars released from 1988 to 2009. Values for (a) and (b) are for 2010. Values for (c) and (d) represent the means of 2009 and 2010.

\section{Responses to Degraining}

To assess whether grain growth among the cultivars was limited by grain source or grain sink size, a degraining treatment was performed at GS61 +14 d. Grain growth responses to degraining of approximately 0 to $10 \%$ are indicative of sink limitation of grain growth, whereas those of approximately 10 to $20 \%$ are indicative of colimitation of grain growth by sink during the earlier phase of grain fill and source during the latter phase of grain fill (Acreche and Slafer, 2009). It was hypothesized that the extent of sink limitation of grain growth may have decreased with plant breeding, with genetic gains in postanthesis source not matching those in sink. Averaging across cultivars, degraining increased grain weight from 42.7 (control treatment) to $45.0 \mathrm{mg}$ (degraining treatment) (5.5\%; $P<0.001$; Table 7). Only weakly significant differences were found among cultivars in the percentage increase in grain weight in response to degraining in the range 0.5 to $13.2 \%(P=0.097$; Table 7$)$, and the interaction between degraining treatment and cultivar was only weakly significant $(P=0.087)$. There was no association among genotypes between the percentage increase in grain weight with degraining and YoR. Stem-and-leaf-sheath weight per shoot was increased from $1.64 \mathrm{~g}$ in the control to $1.79 \mathrm{~g}$ in the degraining treatment $(9.6 \% ; P<0.001)$, and there was a trend for the percentage increase to differ among cultivars in the range 2.2 to $21.0 \%(P=0.07)$. The association between the percentage increase in stem-andleaf-sheath weight per shoot with degraining and YoR was not significant.

\section{Trait Correlations}

A biplot showing associations between grain yield, yield components, and physiological traits is shown in Fig. 5. The biplot confirms the strong positive correlations between each of aboveground biomass, grain weight, plant height, and grain yield among the 12 cultivars. The positive correlation between FE and grains per square meter and between each of preanthesis stomatal conductance and postanthesis CTD and grain yield were also confirmed. Spike partitioning index was negatively correlated with grain yield and plant height. The positive association between rachis length per spikelet and grain weight was also confirmed. 


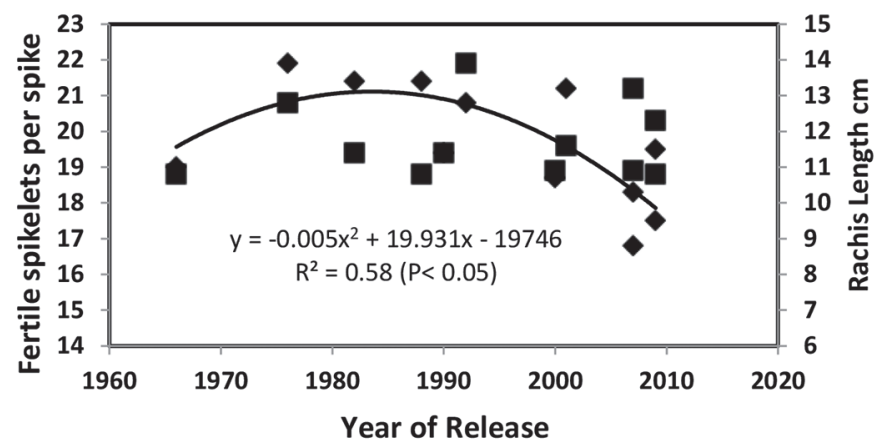

c)

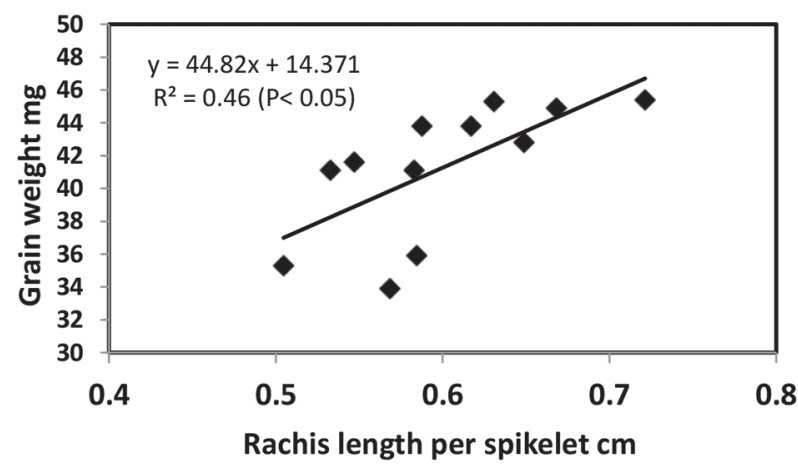

b)
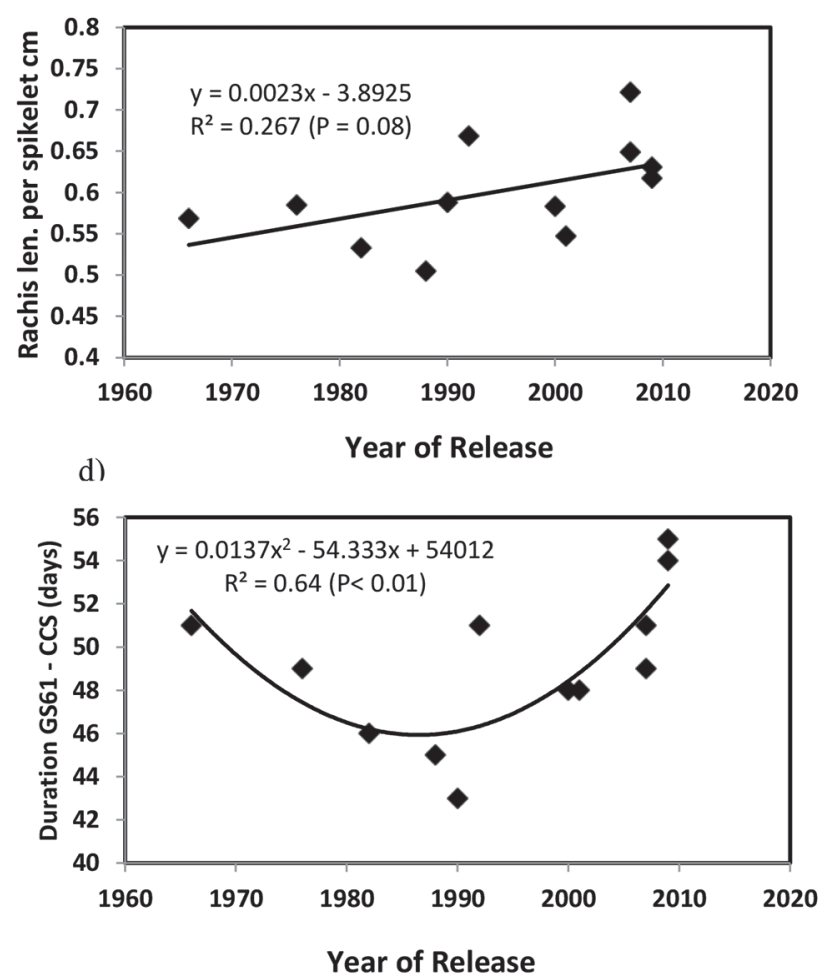

Figure 4. Regression of (a) fertile spikelets per spike (diamonds) and rachis length (squares) on year of release, (b) rachis length per spikelet on year of release, (c) grain weight on rachis length per spikelet, and (d) duration from anthesis (GS61) to complete canopy senescence (CCS) on year of release for 12 CIMMYT spring wheat cultivars. Values represent the mean of 2009 and 2010.

\section{DISCUSSION}

First we will discuss the physiological basis of the genetic gains in grain yield and associated changes in physiological traits with plant breeding in the CIMMYT spring wheat cultivars, including changes in resource capture and assimilate allocation in the pre- and postanthesis periods. Then, we will discuss the implications for future wheat breeding.

\section{Genetic Progress in Grain Yield and Yield Components}

Grain yield potential increased linearly in spring wheat cultivars released in CIMMYT from 1966 to 2009 by $30 \mathrm{~kg} \mathrm{ha}^{-1}$ $\mathrm{yr}^{-1}\left(0.59 \% \mathrm{yr}^{-1}\right)$. Previous studies at the same site on sets of historic spring wheat cultivars showed slightly higher rates of genetic gain of $50 \mathrm{~kg} \mathrm{ha}^{-1} \mathrm{yr}^{-1}$ from 1950 to 1982 (Waddington et al., 1986) and $57 \mathrm{~kg} \mathrm{ha}^{-1} \mathrm{yr}^{-1}$ from 1962 to 1988 (Sayre et al., 1997) (expressing grain yield at 0\% moisture content equivalent to the present study). Present results indicated that the rate of genetic progress in CIMMYT spring wheat has slowed but has not plateaued in recent decades. Present results are therefore in agreement with extensive international yield trials that show continued genetic progress in CIMMYT spring wheat in recent decades (Manes et al., 2012; Lopes et al., 2012; Sharma et al., 2012).
In the present study, there was no association between genetic progress in grain yield and grains per square meter. Genetic grain yield progress from 1966 to 2009 was therefore associated with grain weight. The majority of previous studies worldwide showed that grain yield progress in wheat was mainly associated with grains per square meter (e.g., Perry and D'Antuono, 1989; Waddington et al., 1986; Sayre et al., 1997; Abbate et al., 1998; Shearman et al., 2005) rather than individual grain weight. Lopes et al. (2012), however, recently also found grain yield progress of CIMMYT advanced lines from 1977 to 2008 was associated with increased grain weight and not grains per square meter.

The reduction in plant height with the CIMMYT semidwarf cultivars introduced during the 1960s improved grains per square meter by favoring spike partitioning during the preanthesis phase (Fischer and Stockman, 1986). In the study of Waddington et al. (1986) there were two tall varieties and 15 semidwarfs released from 1950 to 1982. In our study, all the cultivars studied were semidwarf genotypes released between 1966 and 2009. This may partly explain why increases in grains per square meter and $\mathrm{HI}$ with plant breeding were observed in the study of Waddington et al. (1986) but not in our study. Most previous studies on wheat did not show genetic progress in grain weight (e.g., Perry and D’Antuono, 1989; Sayre et al., 1997; 
Table 7. Effect of degraining treatment at GS61 $+14 \mathrm{~d}$ on stem and leaf sheath dry matter (Stem DM) per fertile shoot and individual grain weight of 12 CIMMYT spring wheat cultivars released from 1966 to 2009. Values represent means in 2009 and 2010.

\begin{tabular}{|c|c|c|c|c|c|c|}
\hline \multirow{2}{*}{$\begin{array}{c}\text { Cultivar } \\
\text { (year of release) }\end{array}$} & \multicolumn{3}{|c|}{ Stem DM } & \multicolumn{3}{|c|}{ Grain weight } \\
\hline & Control & Degrained & $\%$ increase & Control & Degrained & $\%$ increase \\
\hline & \multicolumn{2}{|c|}{$\mathrm{g} \mathrm{shoot}^{-1}$} & \multicolumn{4}{|c|}{$\longrightarrow \mathrm{mg} \longrightarrow$} \\
\hline Siete Cerros (1966) & 1.62 & 1.82 & 12.5 & 36.0 & 36.2 & 0.5 \\
\hline Pavon (1976) & 1.60 & 1.72 & 7.4 & 38.0 & 39.7 & 4.2 \\
\hline Seri (1982) & 1.58 & 1.74 & 10.8 & 40.6 & 44.0 & 8.3 \\
\hline Bacanora (1988) & 1.34 & 1.47 & 8.7 & 37.5 & 39.6 & 5.8 \\
\hline Attila (1990) & 1.40 & 1.69 & 20.1 & 44.6 & 47.2 & 5.8 \\
\hline Baviacora (1992) & 2.08 & 2.24 & 7.6 & 45.1 & 51.0 & 13.2 \\
\hline Tarachi (2000) & 1.62 & 1.66 & 2.2 & 44.4 & 45.4 & 2.1 \\
\hline Tacupeto (2001) & 1.58 & 1.67 & 5.2 & 42.9 & 44.6 & 3.8 \\
\hline Roelfs (2007) & 2.06 & 2.27 & 10.3 & 47.9 & 49.3 & 3.0 \\
\hline Navojoa (2007) & 1.55 & 1.66 & 7.4 & 45.6 & 46.7 & 2.4 \\
\hline Becard (2009) & 1.55 & 1.79 & 15.5 & 45.4 & 48.6 & 7.1 \\
\hline Line 1 (2009) & 1.70 & 1.82 & 7.3 & 44.1 & 48.2 & 9.3 \\
\hline Mean & 1.64 & 1.79 & 9.6 & 42.7 & 45.0 & 5.5 \\
\hline $\mathrm{SED}^{\dagger}$ cultivar $(\mathrm{df}=44)$ & $0.085^{\star \star *}$ & $0.073^{\star \star \star}$ & $4.65^{\ddagger}$ & $1.44^{\star \star \star}$ & $0.75^{\star \star \star}$ & $3.78^{\ddagger}$ \\
\hline Correlation (yr of release) & 0.21 & 0.16 & -0.18 & $0.85^{\star \star}$ & $0.78^{\star \star}$ & 0.16 \\
\hline Correlation (grain yield per shoot) & $0.82^{\star \star}$ & $0.73^{\star \star}$ & $\mathrm{n} / \mathrm{a}^{\S}$ & 0.42 & $0.50^{\dagger}$ & $\mathrm{n} / \mathrm{a}$ \\
\hline
\end{tabular}

** Significant at the 0.01 probability level.

*** Significant at the 0.001 probability level.

+ SED, standard error of the differences.

‡ Significant at the 0.10 probability level.

$\S \mathrm{n} / \mathrm{a}$, not applicable.

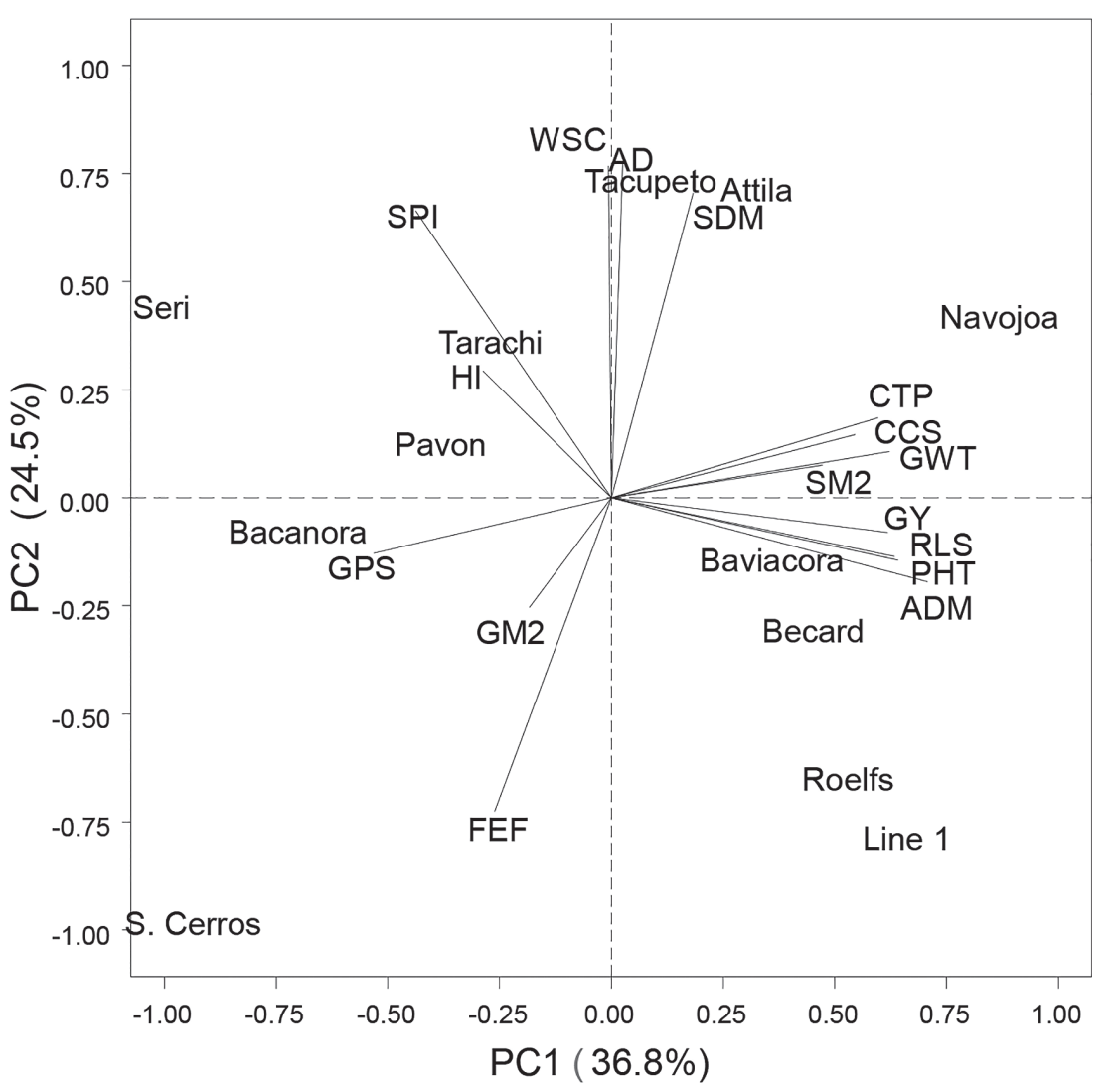

Figure 5. Biplot of grain yield, yield components, and physiological traits for 12 CIMMYT spring wheat cultivars. Values represent the mean of 2009 and 2010. AGDM, aboveground dry matter; CTPOST, canopy temperature depression postanthesis; FE, fruiting efficiency; FSP, fertile spikelets per spike; GM2, grains per m²; GPS, grains per spike; GSPRE, stomatal conductance preanthesis; GWT, grain weight; GY, grain yield; HI, harvest index; PHT, plant height; RCL, rachis length; SDMA, spike dry matter at GS61 +7 d; SM2, spikes per m²; SPI, spike-partitioning index; SRL, rachis length per spikelet; WSC, stem-and-leaf-sheath water-soluble carbohydrate at GS61 +7 d. 
Brancourt-Hulmel et al., 2003; Shearman et al., 2005; Brisson et al., 2010; Acreche et al., 2008). With the introduction of the semidwarf cultivars, there was a tendency for grain weight to decrease associated with more grains in distal positions in spikelets with lower PGW (Waddington et al., 1986). Nevertheless, a few recent studies have indicated that grain weight has contributed to yield progress (Cox et al., 1988; Morgounov et al., 2010; Tian et al., 2011; Zheng et al., 2011; Lopes et al., 2012). Our results indicated that PGW has likely increased and contributed to the genetic gains in final grain weight, since grain weight in the degrained spikes increased linearly with YoR. Where source per grain is effectively increased by $100 \%$ in the degrained spikes, the final grain dry weight is an indicator of PGW. Our results showed no change with plant breeding in either rachis length or fertile spikelets per spike and no correlation between these two traits among genotypes, but indicated rachis length per spikelet increased with YoR and was linearly positively associated with grain weight. It is possible that an increase in rachis length per spikelet favored larger PGW through either increasing spike photosynthesis per grain during the critical phase before (Calderini et al., 1999a; Ugarte et al., 2007) or after (Calderini et al., 1999b) anthesis for determination of PGW or alleviating mechanical constraints to the volume of the floret cavities within the spike. The increase in grain weight in the CIMMYT spring wheats over the 43-yr period may have been partly associated with direct selection for larger grains associated with increased seedling vigor.

Present results indicated the duration from GS61 to CCS increased from approximately 1980. Overall, postanthesis senescence duration was not associated with grain yield or grain weight among the 12 cultivars, but among the 10 cultivars released since 1982 there was a trend for a positive linear association between CCS and each of grain yield $\left(R^{2}=0.28, P=0.07\right)$ and grain weight $\left(R^{2}=0.36, P\right.$ $<0.05)$. These results are consistent with a previous study, which attributed recent genetic increases in grain yield in CIMMYT spring wheats partly to postheading stay-green traits (Lopes et al., 2012). Further work is justified to test whether the genetic gains in grain yield associated with extended senescence duration were related to a delayed onset or a slower rate of canopy senescence.

\section{Genetic Progress in Physiological Components of Grain Yield}

Results showed that plant height has increased linearly with plant breeding. This increase was positively associated with aboveground biomass, which appeared to explain most of the genetic progress in grain yield. The increase in harvest biomass was mostly explained by increased postanthesis AGDM accumulated from GS61 $+7 \mathrm{~d}$ to harvest, which was linearly associated with harvest biomass among cultivars $\left(R^{2}=0.55, P<0.05\right)$; whereas, preanthesis biomass accumulated from sowing to GS61 $+7 \mathrm{~d}$ was not associated with harvest biomass $\left(R^{2}=0.18, P=0.18\right)$ among the cultivars. These results support the idea that improving harvest biomass through selecting for taller cultivars among semidwarf genotypes has been a target in recent breeding strategies at CIMMYT. It is possible the raisedbed planting system used in the experiments, and which is used in the CIMMYT bread wheat yield potential selection breeding trials at Ciudad Obregon, may have favored the selection of taller lines, with taller lines being better adapted to capture radiation in the $50-\mathrm{cm}$ gap between beds within a plot during vegetative growth before canopy closure. For example, Fischer et al. (2005), in the same site in northwest Mexico, reported the response of range of bread wheat cultivars to raised-bed plots compared with flat plots under full irrigation during the period 1988 to 2005. Results suggested that the main consideration determining the responses to raised-bed planting system was the ability of the cultivar to capture the solar radiation falling in the gap between the beds in the critical preanthesis period therefore favoring taller, later, and less-erect genotypes. This may partly explain the positive association between plant height and AGDM in the present experiments observed for AGDM at both GS61 $+7 \mathrm{~d}\left(R^{2}=0.33\right.$, $P=0.05)$ and harvest $\left(R^{2}=0.43, P<0.05\right)$ among the 12 genotypes. Present results showed no genetic gain in CGR during the stem-elongation phase but a linear genetic gain in preanthesis stomatal conductance $\left(R^{2}=0.32, P=0.06\right)$ and a positive correlation between preanthesis stomatal conductance and grain yield $\left(R^{2}=0.43, P<0.05\right)$. Fischer et al. (1998) reported similar effects for CGR and preanthesis stomatal conductance from 1962 to 1988 in CIMMYT spring wheat releases. The trend for aboveground DM at GS61 +7 d to increase with YoR in our study is consistent with the increase in stomatal conductance preanthesis. However, the increased AGDM at GS61 +7 $\mathrm{d}$ did not lead to more grains per square meter, mainly because SPI decreased over the 43-yr period from 0.25 to 0.23; spike DM per square meter at GS61 +7 d did not change with YoR. Therefore, it is possible the correlation between preanthesis stomatal conductance and grain yield was a spurious correlation with both traits increasing with YoR but not directly mechanistically linked.

Turning to consider changes in resource-capture traits during the postanthesis period, our results showed genetic progress in grain weight in northwest Mexico has not been associated with changes in stem WSC accumulation or stem WSC remobilization. Consequently, grain weight increases were apparently associated with increases in current photosynthesis postanthesis. This is consistent with a linear increase in postanthesis CTD with YoR, indicative of an increase in canopy photosynthesis during grain filling and a positive linear association between postanthesis CTD and grain yield $\left(R^{2}=0.66, P<0.001\right)$ and grain 
weight $\left(R^{2}=0.27, P=0.08\right)$. In the $1 \mathrm{yr}$ in which stomatal conductance was measured (2010), there was a positive linear relationship between postanthesis CTD and postanthesis stomatal conductance as expected $\left(R^{2}=0.46, P\right.$ $<0.05)$, although postanthesis stomatal conductance itself was not associated with grain yield. Several previous studies also showed phenotypic correlations between CTD and genetic grains in grain yield among CIMMYT wheat releases (e.g., Fischer et al., 1998 and Lopes et al., 2012). Overall the contribution of stem WSC to grain yield in the current study (calculated as stem WSC remobilization as a proportion of grain yield) was relatively low, varying among cultivars in the range 0.05 to 0.13 compared with some other field investigations, for example, 0.21 reported by Borrell et al. (1989) for spring wheat in field experiments in Australia and a range of 0.23 to 0.39 reported by Foulkes et al. (2002) for six winter wheat cultivars in experiments in the United Kingdom under irrigated conditions. Shearman et al. (2005) found a range of stem WSC of 244 to $391 \mathrm{~g} \mathrm{~m}^{-2}$ measured shortly after anthesis for eight winter wheat cultivars introduced from 1972 to 1995 in the United Kingdom and a positive correlation with grain yield $\left(R^{2} 0.51, P<0.05\right)$. Present results could indicate that under the high-radiation environment in northwest Mexico, stem WSC is likely to be a less important yield determinant than in lower-radiation environments, for example, the United Kingdom. The trend for differences in grain weight responses to degraining among cultivars $(P=0.087)$ suggested differences in source-sink balance among the cultivars. Results indicated that most cultivars in this historic set were generally sink limited rather than source limited or colimited by source and sink. Several previous studies concluded grain growth of wheat was mainly sink limited under optimal conditions (Borras et al., 2004; Snyder et al., 1993; Miralles and Slafer, 1995; Slafer and Savin, 1994; Cartelle et al., 2006). However, Acreche and Slafer (2009) reported that for wheat genotypes released from 1940 to 2005 in Spain, grain weight was unchanged by removing the upper half of the spike in the old cultivars but increased in the newest cultivars. They suggested the modern cultivars exhibited a colimitation of grain growth by source and sink. Fischer and HilleR is Lambers (1978) also reported in responses to a treatment that reduced grains per spike by about $80 \%$, old tall bread wheats showed low source limitation (final grain weight response $<10 \%$ ), whereas most modern semidwarf cultivars showed responses up to 50\%) and higher grain yields. It is possible that some of the cultivars in the present study also exhibited colimitation of grain growth by source and sink, that is, those with grain weight response to degraining $>10 \%$. Nevertheless, our results did not indicate any systematic change in the extent of sink limitation with plant breeding since the proportional grain weight response to degraining did not change with YoR.

\section{Implications for Future Wheat Breeding}

Since the introduction of semidwarfing genes into spring wheat germplasm at CIMMYT, our results indicated the present strategy to increase yield in irrigated, high-potential environments has increased harvest biomass production while maintaining HI. The increase in biomass appears to have contributed to increases in grain yield through heavier grains rather than more grains per square meter. Therefore, relevant future investigations may include the mechanistic basis of genetic gains in PGW involving the regulation of biochemical and structural properties of the ovary and pericarp cell walls before and after anthesis (Foulkes et al., 2011). The basis of the positive relationship between rachis length per spikelet and PGW we detected should also be further investigated, that is, whether this an allometric relationship with larger spikelets relating to larger PGW or whether there are also effects of enhanced spike photosynthesis per spikelet or removal of physical restrictions to grain development with increased size of glumes, paleas, and lemmas. Our results suggested that recent gains in biomass since approximately 1985 were associated with a tendency for a decrease in $\mathrm{HI}$ from $\sim 0.47$ to 0.43 , in turn, associated with increased plant height. The plant height of the most recently introduced CIMMYT spring wheat was $\sim 100 \mathrm{~cm}$, which is significantly higher than the optimum range of plant height of 70 to $90 \mathrm{~cm}$ reported for modern wheat cultivars in many environments worldwide grown on flat planting systems, for example, in China (Zhou et al., 2007; Zheng et al., 2011), the United Kingdom (Clarke et al., 2012), Spain (Sanchez-Garcia et al., 2013), and Australia (Sadras et al., 2012). There may be limited scope to exploit plant height further for enhancing aboveground biomass, as further plant height increases would likely have implications for decreased lodging resistance (Berry et al., 2007). Therefore, for future gains in yield potential of CIMMYT spring wheats it will be important to identify strategies for increasing grain sink while maintaining plant height (Foulkes et al., 2011; Reynolds et al., 2012). It can be speculated that increasing plant height may have also been an advantageous trait for biomass production with regard to the raised-bed planting system in the present experiment, with taller lines being better adapted to capture radiation in the $50-\mathrm{cm}$ gap between beds within a plot during vegetative growth before canopy closure and also during the critical period determining grain number from booting to anthesis (Fischer et al., 2005). There was positive linear relationship between plant height and AGDM at GS31 among the 12 cultivars $\left(R^{2}=0.50, P<0.01\right.$; data not shown).

Our results indicated that, theoretically, a grain yield of $15.30 \mathrm{t} \mathrm{ha}^{-1}$ could be achieved under irrigated conditions in northwest Mexico by combining the maximum values of fertile-shoot AGDM at GS61 +7 d (1271 $\mathrm{g} \mathrm{m}^{-2}$ ), SPI (0.284), FE (83.1 grains $\mathrm{g}^{-1}$ ), and PGW (51.0 $\mathrm{mg}$ ) expressed among the 12 cultivars. Future progress 
will require an improved understanding of any tradeoffs between these traits. Present results indicated a linear negative relationship between grains per square meter and grain weight $\left(R^{2}=0.31, P=0.06\right)$. Although the association between SPI and FE was not significant among the 12 cultivars, there was a linear negative relationship between SPI and FE among the eight cultivars released since 1990 $\left(R^{2}=0.73, P<0.01\right)$. A negative relationship between grains per square meter and grain weight has been frequently observed among wheat genotypes (Foulkes et al., 2011) and a negative relationship between SPI and FE in wheat has also previously been reported in some studies (e.g., Gaju et al., 2009; González et al., 2011; Lázaro and Abbate, 2012). With regard to the trade-off between grains per square meter and grain weight, it is encouraging that results on a Bacanora (high grain per square meter) $\times$ Weebil (high grain weight) spring wheat double-haploid cross in Chile showed it is possible to combine high grain number and grain weight in double-haploid lines with yield gains of 17 and $27 \%$ in two seasons compared to the highest yielding parent Weebil, and there was no evidence for a strong source limitation of grain growth during grain filling (Bustos et al., 2013). The physiological basis of the trade-off between SPI and FE is still unclear. One possible avenue to minimize the trade-off may be improvement of vascular connections within the rachilla, since floret fertility of more distal florets still may be limited by resistance according to the vascular connections within the rachilla (Bancal and Soltani, 2002). Future work to enhance wheat yields should also seek to enhance stay-green, for example, by maximizing canopy $\mathrm{N}$ accumulation and slowing postanthesis N remobilization (Derkx et al., 2012; Gaju et al., 2011, 2014). In addition, the root system of modern wheat may not be large enough at depth to take up sufficient water and nutrients to support future gains in biomass, so breeders should also consider strategies for deeper root distribution in future breeding programs alongside strategies to raise aboveground biomass (Reynolds et al., 2007; Lynch, 2007). The present results also confirm the scope for the application of canopy temperature and stomatal conductance as selection criteria for wheat yield potential in irrigated, high-potential environments (Fischer et al., 1998; Reynolds et al., 2007).

\section{Acknowledgments}

The authors would like to express their gratitude to the Grains Research Development Corporation of Australia and the Libyan government for supporting this research. They also thank Eugenio Perez, Araceli Torres, and Mayra Barcelo Garcia for technical support with field experiments.

\section{References}

Abbate, P.E., D.H. Andrade, L. Lazaro, J.H. Baraitti, H.G. Beradocco, V.H. Inza, and F. Marturano. 1998. Grain yield in recent Argentine wheat cultivars. Crop Sci. 38:1203-1209. doi:10.2135/cropsci1998.0011183X003800050015x

Acreche, M.M., and G.A. Slafer. 2009. Grain weight, radiation interception and use efficiency as affected by sink-strength in Mediterranean wheats released from 1940 to 2005. Field Crops Res. 110:98-105. doi:10.1016/j.fcr.2008.07.006

Acreche, M.M., G. Briceno-Felix, J.A. Martin Sanchez, and G.A. Slafer. 2008. Physiological bases of genetic gains in Mediterranean bread wheat yield in Spain. Eur. J. Agron. 28:162-170. doi:10.1016/j.eja.2007.07.001

Austin, R.B., M.A. Ford, and C.L. Morgan. 1989. Genetic improvement in the yield of winter wheat: A further evaluation. J. Agric. Sci. (Camb.) 112:295-301. doi:10.1017/S0021859600085749

Bancal P., and Soltani F. 2002. Source-sink partitioning. Do we need Münch? J. Exp. Bot. 53:1919-1928.

Berry P.M., R. Sylvester-Bradley, and S. Berry. 2007. Ideotype for lodging resistant wheat. Euphytica 154:165-179.

Beche, E., G. Benin, C.L. da Silva, L.B. Munaro, and J.A. Marchese. 2014. Genetic gain in yield and changes associated with physiological traits in Brazilian wheat during the 20th century. Eur. J. Agron. 61:49-59. doi:10.1016/j.eja.2014.08.005

Borras, L., G.A. Slafer, and M.E. Otegui. 2004. Seed dry weight response to source-sink manipulation in wheat, maize, and soybean: A quantitative reappraisal. Field Crops Res. 86:131146. doi:10.1016/j.fcr.2003.08.002

Borrell, A.K., L.D. Incoll, R.J. Simpson, and M.J. Dalling. 1989. Partitioning of dry matter and the deposition and use of stem reserves in a semi-dwarf wheat crop. Ann. Bot. (Lond.) 63:527-539.

Brancourt-Hulmel, M., G. Doussinault, C. Lecomte, P. Berard, B. Le Buanec, and M. Trottet. 2003. Genetic improvement of agronomic traits of winter wheat cultivars released in France from 1946 to 1992. Crop Sci. 43:37-45. doi:10.2135/cropsci2003.3700

Brisson, N., P. Gate, D. Gouache, G. Charmet, F.X. Oury, and F. Huard. 2010. Why are wheat yields stagnating in Europe. A comprehensive data analysis for France. Field Crops Res. 119:201-212. doi:10.1016/j.fcr.2010.07.012

Bustos, D.V., A.K. Hasan, M.P. Reynolds, and D.F. Calderini. 2013. Combining high grain number and weight through a DH-population to improve grain yield potential of wheat in high-yielding environments. Field Crops Res. 145:106-115. doi:10.1016/j.fcr.2013.01.015

Calderini, D.F., L.G. Abeledo, R. Savin, and G.A. Slafer. 1999 b. Final grain weight in wheat as affected by short periods of high temperature during pre- and postanthesis under field conditions. Aust. J. Plant Physiol. 26:453-458. doi:10.1071/PP99015

Calderini, D.F., M.P. Reynolds, and G.A. Slafer. 1999a. Genetic gains in wheat yield and main physiological changes associated with them during the 20th century. In: E.H. Satorre and G.A. Slafer, editors, Wheat: Ecology and physiology of yield determination. Food Product Press, New York. p. 351-377.

Cartelle, J., A. Pedro, R. Savin, and G.A. Slafer. 2006. Grain weight responses to postanthesis spikelet-trimming in an old and a modern wheat under Mediterranean conditions. Eur. J. Agron. 25:365-371. doi:10.1016/j.eja.2006.07.004 
Clarke, S., R. Sylvester-Bradley, J. Foulkes, D. Ginsburg, O. Gaju, J.P. Werner, E. Flatman, and L. Smith-Reeve. 2012. Adapting wheat to global warming or 'ERYCC' earliness and resilience for yield in a changing climate. HGCA Research and Development Report 496. Home-Grown Cereals Authority, London.

Cox, T.S., J.P. Shroyer, L. Ben-Hui, R.G. Sears, and T.J. Martin. 1988. Genetic improvement in agronomic traits of hard red winter wheat cultivars from 1919 to 1987. Crop Sci. 28:756776. doi:10.2135/cropsci1988.0011183X002800050006x

Derkx, A., S. Orford, S. Griffiths, M.J. Foulkes, and M.J. Hawkesford. 2012. Identification of differentially senescing mutants of wheat and impacts on yield, biomass and nitrogen partitioning. J. Integr. Plant Biol. 54:555-566. doi:10.1111/j.17447909.2012.01144.x

Fischer, R.A. 1983. Wheat. In: Proceedings of the Symposium on Potential Productivity of Field Crops under Different Environments, Los Baños, Philippines, 22-26 Sept. 1980. Int. Rice Res. Inst., Los Baños. p. 129-154.

Fischer, R.A., and HillR is Lambers, D., 1978. Effect of environment and cultivar on source limitation to grain weight in wheat. Aust. J. Agric. Res. 29: 433-458.

Fischer, R.A., D. Rees, K.D. Sayre, Z.M. Lu, A.G. Condon, and A.L. Saavedra. 1998. Wheat yield progress associated with higher stomatal conductance and photosynthetic rate and cooler canopies. Crop Sci. 38:1467-1475. doi:10.2135/cropsci19 98.0011183X003800060011x

Fischer, R.A., K. Sayre, and I. Ortiz-Monasterio. 2005. The effect of raised bed planting on irrigated wheat as influenced by variety and row spacing. In: C.A. Roth, R.A. Fischer, and C.A. Meisner, editors, Evaluation and performance of permanent raised bed cropping systems in Asia, Australia and Mexico. ACIAR Proceedings No. 121. Australian Centre for Int. Agric. Res., Canberra, ACT. p. 1-11.

Fischer, R.A., and Y.M. Stockman. 1986. Increased kernel number in Norin 10-derived dwarf wheat: Evaluation of the cause. Aust. J. Plant Physiol. 13:767-784. doi:10.1071/PP9860767

Foulkes, M. J., Scott, R. K., and Sylvester-Bradley, R. 2002. The ability of wheat cultivars to withstand drought in UK conditions: Formation of grain yield. J Agric Sci. (Camb.) 138:153-169.

Foulkes, M.J., G.A. Slafer, W.J. Davies, P.M. Berry, R. SylvesterBradley, P. Martre, D.F. Calderini, S. Griffiths, and M.P. Reynolds. 2011. Raising yield potential of wheat. (III) Optimizing partitioning to grain while maintaining lodging resistance. J. Exp. Bot. 62:469-486. doi:10.1093/jxb/erq300

Gaju, O., V. Allard, P. Martre, J.W. Snape, E. Heumez, J. LeGouis, D. Moreaub, M. Bogard, S. Griffiths, S. Orford, S. Hubbart, and M.J. Foulkes. 2011. Identification of traits to improve he nitrogen-use efficiency of wheat genotypes. Field Crops Res. 129:139-154. doi:10.1016/j.fcr.2011.05.010

Gaju, O., M.P. Reynolds, D.L. Sparkes,, and M.J. Foulkes. 2009. Relationships between large-spike phenotype, grain number and yield potential in spring wheat. Crop Sci. 49: 961-973.

Gaju O., M.P. Reynolds, D.L. Sparkes, S. Mayes, G. Ribas-Vargas, M.J. Foulkes. 2014. Relationships between physiological traits, grain number and yield potential in a wheat $\mathrm{DH}$ population of large spike phenotype Field Crops Research 164:126-135

Gay, A.P., D.J. Stokes, R.M. Weightman, and R. Sylvester-Bradley. 1998. How to run a reference crop. HGCA Research and Development Project Rep. 151. Home-Grown Cereals Authority, London.
González, F.G., D.J. Miralles, and G.A. Slafer. 2011. Wheat floret survival as related to pre-anthesis spike growth. J. Exp. Bot. 62:4889-4901.

Graybosch, R.A., and C.J. Peterson. 2010. Genetic improvement in winter wheat yields in the Great Plains of North America, 1959-2008. Crop Sci. 50:1882-1890. doi:10.2135/cropsci2009.11.0685

Lázaro, L., and P.E. Abbate. 2012. Cultivar effects on relationship between grain number and photothermal quotient or spike dry weight in wheat. J. Agric. Sci. 150: 442-459.

Limon-Ortega, A., K.D. Sayre, R.A. Drijber, and C.A. Francis. 2002. Soil attributes in a furrow-irrigated bed planting system in northwest Mexico. Soil Tillage Res. 63:123-132. doi:10.1016/S0167-1987(01)00230-6

Lopes, M.S., M.P. Reynolds, Y. Manes, R.P. Singh, J. Crossa, and H.J. Braun. 2012. Genetic yield gains and changes in associated traits of CIMMYT spring bread wheat in a "Historic" set representing 30 years of breeding. Crop Sci. 52:1123-1131. doi:10.2135/cropsci2011.09.0467

Lynch, J.P. 2007. Turner review No. 14 roots of the second green revolution. Aust. J. Bot. 55:493-512. doi:10.1071/BT06118

Mackay, I., A. Horwell, J. Garner, J. White, J. McKee, and H. Philpott. 2011. Reanalyses of the historical series of UK variety trials to quantify the contributions of genetic and environmental factors to trends and variability in yield over time. Theor. Appl. Genet. 122:225-238. doi:10.1007/s00122-010-1438-y

Manes, Y., H.F. Gomez, L. Puhl, M.P. Reynolds, H.J. Braun, and R.M. Trethowan. 2012. Genetic yield gains of the CIMMYT international semi-arid wheat yield trials from 1994 to 2010. Crop Sci. 52:1543-1552. doi:10.2135/cropsci2011.10.0574

Matus, I., M. Mellado, M. Pinares, R. Madariaga, and A. del Pozo. 2012. Genetic progress in winter wheat cultivars released in Chile from 1920 to 2000. Chilean J. Agic. Res. 72:303-308.

Miralles, D.J., and G.A. Slafer. 1995. Individual grain weight responses to genetic reduction in culm length in wheat as affected by source-sink manipulations. Field Crops Res. 43:55-66. doi:10.1016/0378-4290(95)00041-N

Morgounov, A., V. Zykin, I. Belan, L. Roseeva, Yu. Zelenskiy, H.F. Gomez-Becerra, H. Budak, and F. Bekes. 2010. Genetic gains for grain yield in high latitude spring wheat grown in Western Siberia in 1900-2008. Field Crops Res. 117:101-112. doi:10.1016/j.fcr.2010.02.001

Peltonen-Sainio, P., L. Jauhiainen, and I.P. Laurila. 2009. Cereal yield trends in northern European conditions: Changes in yield potential and its realisation. Field Crops Res. 110:85-90. doi:10.1016/j.fcr.2008.07.007

Perry, M.W., and M.F. D’Antuono. 1989. Yield improvement and associated characteristics of some Australian spring wheat cultivars introduced between 1860 and 1982. Aust. J. Agric. Res. 40:457-472.

Reynolds, M.P., M.J. Foulkes, R. Furbank, S. Griffiths, J. King, E. Murchie, M. Parry, and G. Slafer. 2012. Achieving yield gains in wheat. Plant Cell Environ. 35:1799-1823. doi:10.1111/ j.1365-3040.2012.02588.x

Reynolds, M.P., P.R. Hobbs, and H.J. Braun. 2007. Challenges to international wheat improvement. J. Agric. Sci. (Camb.) 145:223-227. doi:10.1017/S0021859607007034

Sayre, K.D., S. Rajaram, and R.A. Fischer. 1997. Yield potential progress in short bread wheats in northwest Mexico. Crop Sci. 37:36-42. doi:10.2135/cropsci1997.0011183X003700010006x 
Sadras, V.O., and C. Lawson. 2011. Genetic gain in yield and associated changes in phenotype, trait plasticity and competitive ability of South Australian wheat varieties released between 1958 and 2007. Crop Pasture Sci. 62:533-539. doi:10.1071/CP11060

Sadras, V.O., C. Lawson, and A. Montoro. 2012. Photosynthetic traits in Australian wheat varieties released between 1958 and 2007. Field Crops Res. 134:19-29. doi:10.1016/j.fcr.2012.04.012

Sanchez-Garcia, M., C. Royo, N. Aparicio, J. Martin-Sanchez, and F. Álvaro. 2013. Genetic improvement of bread wheat yield and associated traits in Spain during the 20th century. J. Agric. Sci. 151:105-118. doi:10.1017/S0021859612000330

Sharma, R.C., J. Crossa, G. Velu, J. Huerta-Espino, M. Vargas, T.S. Payne, and R.P. Singh. 2012. Genetic gains for grain yield in CIMMYT spring bread wheat across international environments. Crop Sci. 52:1522-1533. doi:10.2135/cropsci2011.12.0634

Shearman, V.J., R. Sylvester-Bradley, R.K. Scott, and M.J. Foulkes. 2005. Physiological processes associated with wheat yield progress in the UK. Crop Sci. 45:175-185. doi:10.2135/cropsci2005.0175

Slafer, G.A., F.H. Andrade, and E.H. Satorre. 1990. Genetic improvement effects on preanthesis physiological attributes related to wheat grain yield. Field Crops Res. 23:255-263. doi:10.1016/0378-4290(90)90058-J

Slafer, G.A., and R. Savin. 1994. Grain mass change in a semi-dwarf and a standard height wheat cultivar under different sink-source relationships. Field Crops Res. 37:39-49. doi:10.1016/03784290(94)90080-9

Snyder, G.W., D.J. Sammons, and R.C. Sicher. 1993. Spike removal effects on dry matter production, assimilate distribution and grain yields of three soft red winter wheat genotypes. Field Crops Res. 33:1-11. doi:10.1016/0378-4290(93)90091-Z

Tian, Z., Q. Jing, T. Dai, D. Jiang, and W. Cao. 2011. Effects of genetic improvements on grain yield and agronomic traits of winter wheat in the Yangtze River Basin of China. Field Crops Res. 124:417-425. doi:10.1016/j.fcr.2011.07.012
Tottman, R. 1987. The decimal code for growth stages of cereals with illustrations. Ann. Appl. Biol. 110:441-454. doi:10.1111/j.1744-7348.1987.tb03275.x

Ugarte, C., D.F. Calderini, and G.A. Slafer. 2007. Grain weight and grain number responsiveness to preanthesis temperature in wheat, barley and triticale. Field Crops Res. 100:240-248. doi:10.1016/j.fcr.2006.07.010

VSN International. 2010. GenStat software for windows. Release 14. VSN Intl., Hemel Hempstead, UK.

Waddington, S.R., J.K. Ransom, M. Osmanzai, and D.A. Saunders. 1986. Improvement in the yield potential of bread wheat adapted to northwest Mexico. Crop Sci. 26:698-703. doi:10.2135/crops ci1986.0011183X002600040012x

Xiao, Y.G., Z.G. Qian, K. Wu, J.J. Liu, X.C. Xia, W.Q. Ji, and Z.H. He. 2012. Genetic gains in grain yield and physiological traits of winter wheat in Shandong Province, China, from 1969 to 2006. Crop Sci. 52:44-56. doi:10.2135/cropsci2011.05.0246

Yemm, E.W., and A.J. Willis. 1954. The estimation of carbohydrates in plant extracts by anthrone. Biochem. J. 57:508-514.

Zheng, T.C., X.K. Zhang, G.H. Yin, L.N. Wang, Y.L. Han, L. Chen, F. Huang, J.W. Tang, X.C. Xia, and Z.H. He. 2011. Genetic gains in grain yield, net photosynthesis and stomatal conductance achieved in Henan Province of China between 1981 and 2008. Field Crops Res. 122:225-233. doi:10.1016/j. fcr.2011.03.015

Zhou, Y., Z.H. He, X.X. Suic, X.C. Xiaa, X.K. Zhang, and G.S. Zhang. 2007. Genetic improvement of grain yield and associated traits in the Northern China Winter Wheat Region from 1960 to 2000. Crop Sci. 47:245-253. doi:10.2135/cropsci2006.03.0175 